\title{
A basal sphenodontian (Lepidosauria) from the Jurassic of Patagonia: new insights on the phylogeny and biogeography of Gondwanan rhynchocephalians
}

\author{
SEBASTIÁN APESTEGUÍA ${ }^{1 *}$, RAÚL O. GÓMEZ² and GUILLERMO W. ROUGIER ${ }^{3}$ \\ ${ }^{1}$ CONICET-Fundación de Historia Natural 'Félix de Azara'-CEBBAD-Universidad Maimónides, \\ Hidalgo 775, 1405 Buenos Aires, Argentina \\ ${ }^{2}$ CONICET-Departamento de Ciencias Geológicas, Facultad de Ciencias Exactas y Naturales. \\ Universidad de Buenos Aires, Pabellón 2, Ciudad Universitaria, 1428 Buenos Aires, Argentina \\ ${ }^{3}$ Department of Anatomical Sciences and Neurobiology, University of Louisville, 500 S. Preston \\ Street, Louisville, 40292 Kentucky, USA
}

Received 12 January 2012; revised 16 April 2012; accepted for publication 26 April 2012

Herein we describe a new rhynchocephalian taxon from the Middle Jurassic of Patagonia, Argentina, representing the first Jurassic record of the group in South America. The new taxon, consisting of a complete dentary, is ascribed to Sphenodontia based on the presence of a deep and wide Meckelian groove, long posterior process, well-developed coronoid process, and acrodont teeth showing dental regionalization including successional, alternate hatchling, and additional series. This allocation is reinforced by a phylogenetic analysis that places the new taxon in a basal position within a clade of sphenodontians that excludes Diphydontosaurus and Planocephalosaurus. Additionally, the new taxon clusters within a Gondwanan clade with the Indian Godavarisaurus from the Jurassic Kota Formation, sharing the presence of recurved and relatively large posterior successional teeth that are ribbed and bear a peculiar anterolingual groove. This sister-group relationship is intriguing from a palaeobiogeographical viewpoint, as it suggests some degree of endemism during the initial stages of the breakup of Pangaea. We also discuss the ontogenetic stage of the new taxon and provide insights on the evolution of successional dentition in rhynchocephalians.

(C) 2012 The Linnean Society of London, Zoological Journal of the Linnean Society, 2012, 166, 342-360. doi: 10.1111/j.1096-3642.2012.00837.x

ADDITIONAL KEYWORDS: Argentina - Cañadón Asfalto - Central Gondwanan Desert - Gondwana Middle Jurassic - ontogeny - palaeobiogeography - Rhynchocephalia - Sphenodontia - successional dentition.

\section{INTRODUCTION}

Rhynchocephalia (Günther, 1867 sensu Gauthier, Estes \& De Queiroz, 1988) is a clade of lizard-like reptiles that, together with Squamata, constitute the Lepidosauria (Carroll, 1977; Evans, 1984; Benton, 1985; Gauthier et al., 1988). Rhynchocephalians are represented today by the sole genus Sphenodon, the 'tuatara', with only two species inhabiting several

*Corresponding author. E-mail: sebapesteguia@gmail.com islands around New Zealand (Daugherty et al., 1990). The living rhynchocephalians are the remnants of a group that experienced a remarkable Mesozoic diversification, followed by a substantial reduction in the Late Cretaceous, believed by some authors (e.g. Carroll, 1985) to be related to the radiation of the Squamata.

The fossil record of rhynchocephalians dates back to the Late Triassic (Carnian) of North America (Sues \& Olsen, 1990) and Europe (Fraser \& Benton, 1989). Most other Triassic records are also from the northern landmasses, particularly North America (e.g. Sues \& 
Baird, 1993), the UK (e.g. Huene, 1910; Robinson, 1973; Fraser, 1982; Whiteside, 1986), Germany (e.g. Fraser \& Benton, 1989), and China (Wu, 1994). Southern Triassic records include fragmentary material from Africa (Gow \& Raath, 1977; Sues \& Reisz, 1995) and well-preserved clevosaurs from Brazil (e.g. Ferigolo, 1999; Bonaparte \& Sues, 2006). During the Early Jurassic rhynchocephalians continued to be abundant in northern regions including the UK (e.g. Evans, 1980), Mexico (e.g. Clark et al., 1994; Reynoso, 1996, 1997, 2005), and China (Evans, 1992), whereas southern regions only include fragmentary remains from Zimbabwe (Gow \& Raath, 1977), South Africa (Sues \& Reisz, 1995), and India (Evans, Prasad \& Manhas, 2001). The Middle and Late Jurassic record of the group was, up to now, restricted to the Northern Hemisphere, with no records from Gondwanan landmasses. This Laurasian record includes fragmentary material from the UK (Evans, 1992), France (e.g. Cocude-Michel, 1963), and the USA (e.g. Gilmore, 1909; Rasmussen \& Callison, 1981), and well-preserved specimens from Mexico (e.g. Reynoso, 1996). Furthermore, the South American record of rhynchocephalians exhibits a time gap of more than 100 million years, from the Late Triassic (Norian) of Brazil (Caturrita Formation; Ferigolo, 1999) to the early Late Cretaceous (Cenomanian) of Patagonia (Candeleros Formation; Apesteguía \& Novas, 2003).

The Jurassic Cañadón Asfalto Formation of Chubut Province, Patagonia, Argentina (Fig. 1), has yielded the most taxonomically diverse Gondwanan biota of Middle Jurassic age (Escapa et al., 2008; Pol, Rauhut \& Becerra, 2011). This unit was intensively worked by Bonaparte (between 1978 and 1986), providing abundant remains of the eusauropods Patagosaurus fariasi Bonaparte, 1979, and Volkheimeria chubutensis Bonaparte, 1979, and the basal tetanuran Piatnitzkysaurus floresi Bonaparte, 1986, related to Condoraptor currumili Rauhut, 2005, from the same unit. In November 2000, Mr Pablo Puerta, technician at the 'Egidio Feruglio' Museum of Trelew (MEF), in the frame of a fieldtrip led by Dr Oliver Rauhut, discovered a mammalian jaw (Rauhut et al., 2002) that prompted the intensive work of a small microvertebrate locality known as 'Queso Rallado' (Fig. 1). One of us (G. W. R.) and a MEF team intensively worked the locality during the last decade finding frogs, turtles (Sterli, 2008), dinosaurs (Pol et al., 2011), pterosaurs, and mammals (Rougier et al., 2007a, b; L. C. Gaetano \& G. W. Rougier, 2011, unpubl. data).

Herein we describe a new rhynchocephalian from the locality of Queso Rallado, near Cerro Condor
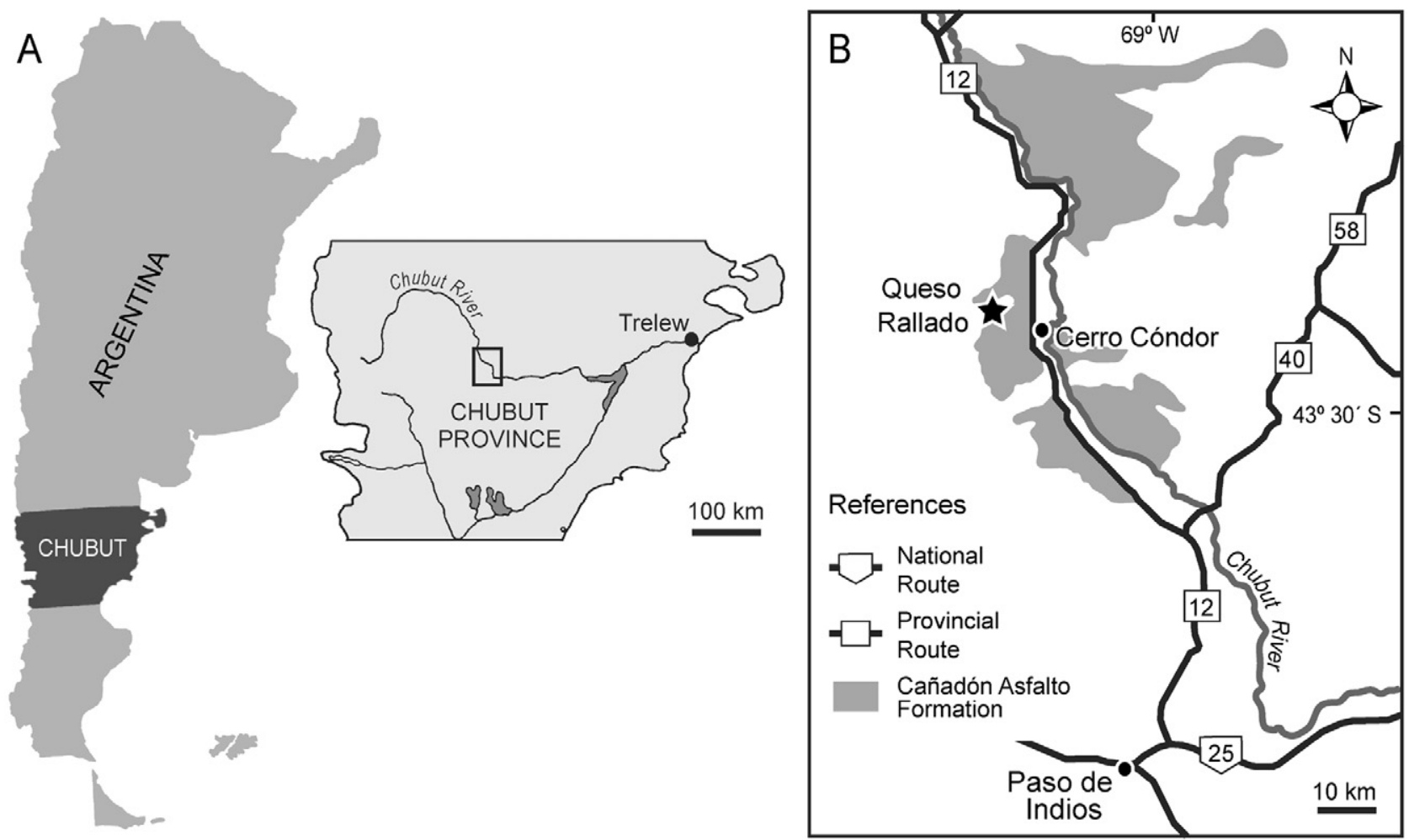

Figure 1. A, map of Argentina and Chubut Province indicating the study area where the new rhynchocephalian was found. B, close-up of the study area showing Queso Rallado locality, near Cerro Cóndor village. 
village (Fig. 1). The material described herein represents the first Jurassic rhynchocephalian from South America as well as the first of Middle Jurassic age from Gondwana, contributing to filling an extensive stratigraphical and morphological gap in the fossil record of the group.

\section{MATERIAL AND METHODS}

The material consists of a nearly complete dentary preserved in two slabs as part (Fig. 2A) and counterpart (Fig. 2B). Both parts were digitally superimposed and considered as one specimen for descriptive and comparative purposes (Fig. 2C), unless stated otherwise. Photographs were taken using a Nikon Coolpix 990 digital camera and measurements were taken from digital images using IMAGE J (Abramoff, Magalhaes \& Ram, 2004).
Anatomical terminology mainly follows that of Harrison (1901) and Romer (1956) with additional terms from Apesteguía (2008). We refer to the dentary and the dentition in general using standard anatomical orientation terms (anterior/posterior; dorsal/ventral; lateral/medial); the tooth orientation terminology (labial/lingual; mesial/distal; basal/apical) of Smith \& Dodson (2003) is used when referring to particular teeth.

The presence of 'caniniform' successional teeth in rhynchocephalians has been considered of great systematic value by some authors (e.g. Gauthier et al., 1988; Reynoso, 1996, 2003). However, the precise homology between these 'caniniform' teeth and other successionals remains uncertain in fossil taxa. Therefore, we use herein the term 'caniniform' as a functionally defined morphological concept, free of homology assumptions (Vogt, Bartolomaeus \& Giribet, 2010); accordingly, the term appears in
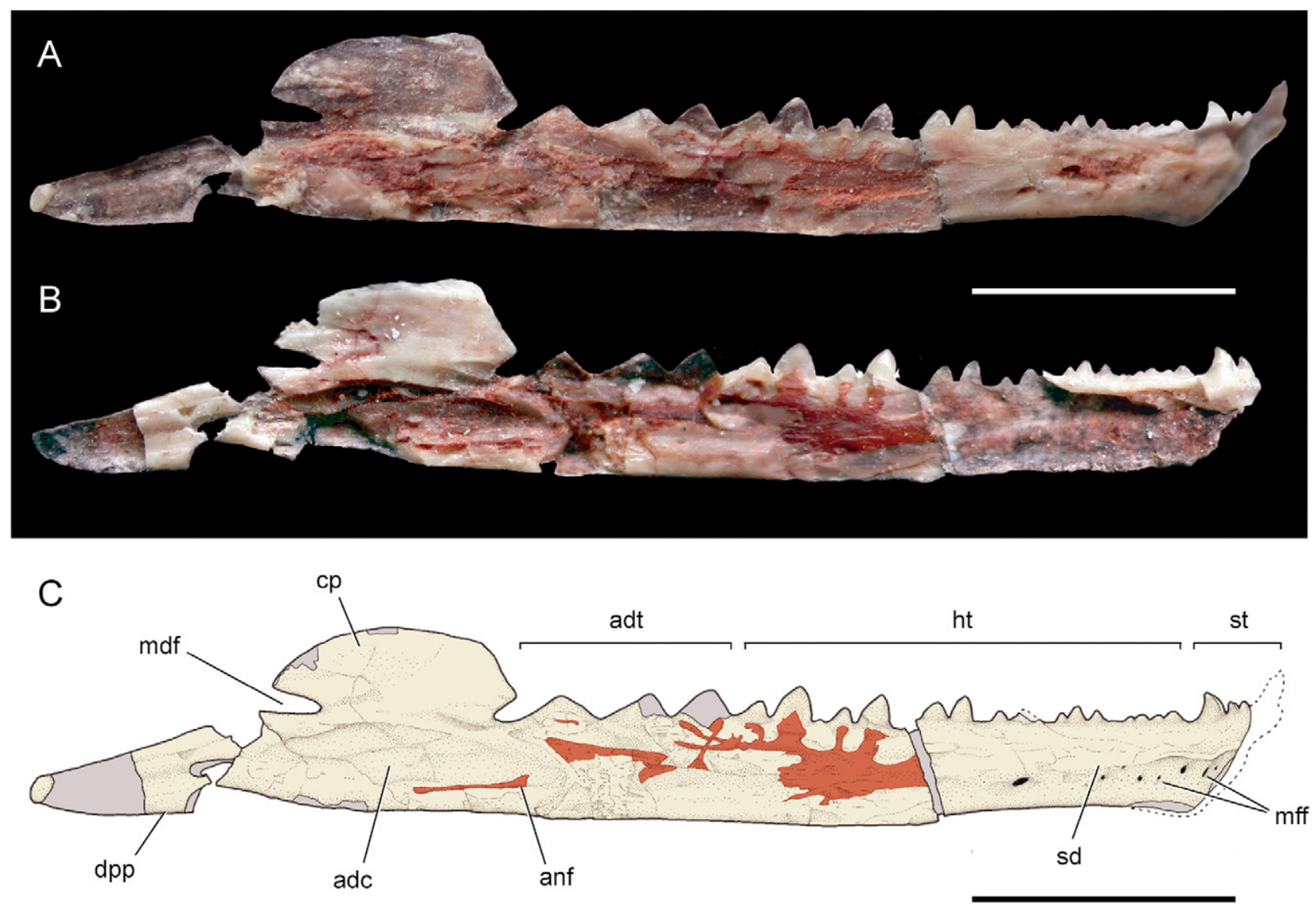

Figure 2. Sphenocondor gracilis gen. et sp. nov., holotype (MPEF-PV 2358), right dentary. A, general view of dentary in slab A. B, general view of dentary in slab B (reversed). C, partial restoration combining part and counterpart. Dotted line depicts the symphyseal region preserved as an impression in slab A. Abbreviations: adc, adductor fossa; adt, additional teeth; anf, angular facet; cp, coronoid process; dpp, dentary posterior process; ht, hatchling teeth; mdf, mandibular foramen; mff, mental foramina; sd, secondary bone; st, successional teeth. Scale bars $=5 \mathrm{~mm}$. 
quotes throughout the text. This way, a 'caniniform' is any successional tooth in the anterior region of the dental line that detaches and remains substantially larger than adjacent teeth.

The name Rhynchocephalia Günther (1867) was originally erected for the genus Sphenodon and the Triassic rhynchosaurs were included later (Nopsca, 1928; Romer, 1956), although subsequent work removed the latter forms from the group (Benton, 1985; Evans, 1988). Consequently, in spite of the former link of rhynchosaurs to rhynchocephalians and the misleading name similarity, Estes (1983) then proposed Sphenodontida to encompass Sphenodon and allies. Known taxa and hypotheses of interrelationships within the group have considerably increased since then and, hence, the contents of different suprageneric taxa vary accordingly. The more widespread uses of the names Rhynchocephalia, Sphenodontia, and its vernacular derivatives (e.g. Reynoso, 1996; Evans et al., 2001) are followed and employed here.

The methodology employed in the phylogenetic analysis is detailed under the corresponding heading (see Phylogenetic analysis).

\section{SYSTEMATIC PALAEONTOLOGY}

LEPIDOSAURIA DUMERIL ET BIBRON, 1839

(SENSU EVANS, 1984)

RHYNCHOCEPHALIA GÜNTHER, 1867

(SENSU GAUTHIER ET AL., 1988)

SPHENODONTIA WILLISTON, 1925

(SENSU BENTON, 1985)

\section{SPHENOCONDOR GEN. NOV.}

Type species: Sphenocondor gracilis sp. nov.

Diagnosis: As for type and only known species.

Etymology: 'Spheno' refers to the Sphenodontia, and 'condor' is after the nearby village of Cerro Cóndor, Chubut Province, Argentina.

\section{SPHENOCONDOR GRACILIS SP. NOV.}

Etymology: The specific epithet 'gracilis' refers to the slenderness of the jaw.

Holotype: MPEF-PV 2358, a single dentary preserved in two slabs as part (A) and counterpart (B).

Locality and horizon: Queso Rallado locality, about $2.3 \mathrm{~km}$ north-west of Cerro Cóndor village, $360 \mathrm{~km}$ west from Trelew, Chubut Province, Argentina (Fig. 1). The bearing beds consist of silicified mudstones within series of mudstones and limestones that are part of the Lower Member of the Cañadón Asfalto Formation (Rougier et al., 2007b) and that were deposited in a lacustrine carbonate environment (Figari, Courtade \& Constantini, 1996). The age of this unit has usually been considered as Callovian (Proserpio, 1987) or Callovian-Oxfordian (e.g. Tasch \& Volkheimer, 1970; Musacchio, Beros \& Pujana, 1990; Figari \& Courtade, 1993; Page et al., 1999; Silva Nieto etal., 2002; Cabaleri et al., 2010). However, recent radiometric data (Cuneo \& Bowring, 2010) suggest that it might be older (beginning its deposition in the Toarcian). Despite some difficulty in establishing precise correlations between the Queso Rallado Quarry and the dated beds, the age of the fossils is almost certainly Middle Jurassic.

Diagnosis: Small sphenodontian rhynchocephalian differing from all other rhynchocephalians in having the following combination of features: slender lower jaw with a low and squared coronoid process; dentary posterior process as long as the base of the coronoid process; at least two strongly recurved and profusely striated successional teeth with no separation between them (differing from Theretairus and Sphenovipera) and with an anterior flange marked by a wide canal; unadorned additional teeth; two dentine types organized in a radiating pattern; symphysis anterodorsally projected; adductor fossa centred under the coronoid process; and alternate hatchling dentition organized in three groups of different size and showing a slight basal constriction. These last three characters constitute autapomorphic features.

\section{DESCRIPTION AND TAXONOMIC COMPARISONS}

\section{Dentary}

The lower jaw is very slender and, as in basal forms (e.g. Diphydontosaurus avonis Whiteside, 1986), the dentary represents about $90 \%$ of the total length of the jaw. The height of the dentary varies along the jaw (Table 1), from $2 \mathrm{~mm}$ in the precoronoid region to $3.72 \mathrm{~mm}$ at the level of the coronoid process. The dental margin of the dentary is about $15.9 \mathrm{~mm}$ from the symphysis to the anterior part of the coronoid process, and can be divided into successional, hatchling, and additional regions, based on the dentition (Fig. 2). The presence of a deep and wide Meckelian groove on the medial side of the mandible is only evident in the posterior part of slab B (Fig. 2B). The lateral surface of the dentary, as preserved in slab A (Fig. 2A), shows development of secondary bone (secondary dentine of Fraser, 1986) below the tooth row (at least on the anterior portion of the dentary). This feature has been regarded as a character of derived rhynchocephalians, being absent in basal taxa such 
Table 1. Measurements (in mm) of the holotype of Sphenocondor gracilis gen. et sp. nov. (MPEF-PV 2358)

\begin{tabular}{lc}
\hline Measurements & Value \\
\hline Total length of dentary & 24.96 \\
Total length of jaw (estimated) & 26.4 \\
Maximum height of jaw at symphysis & 2.5 \\
Minimum height of jaw (anteriorly) & 1.42 \\
Height of jaw at coronoid process & 3.72 \\
Length of coronoid process at base & 4.53 \\
Length of coronoid process at top & 3.07 \\
Height of coronoid process & 1.73 \\
Length of posterior process & 5.29 \\
Height of last successional tooth & 0.54 \\
Length of adductor fossa & 5.82 \\
Height of adductor fossa & 1.18 \\
\hline
\end{tabular}

as Gephyrosaurus and Diphydontosaurus (Fraser, 1988; Jones, 2006; Jones et al., 2009).

The ventral margin of the dentary is rather straight as in basal rhynchocephalians and some derived forms such as Cynosphenodon huizachalensis Reynoso, 1996 and 'Sphenodontid B' from the Early Cretaceous beds of Anoual, Morocco (Evans \& Sigogneau-Russell, 1997).

The symphyseal region is badly damaged, but a large and pointed fragment is evident in slab A (Fig. 2A). This fragment might represent part of a large successional tooth or a symphyseal spur (crowned or not by a symphyseal tooth), although its poor preservation prevents us from confirming its identity. A symphyseal spur occurs in Sphenodon, Sphenovipera, Cynosphenodon, Rebbanasaurus (Evans et al., 2001; Reynoso, 2005; Fig. 4F), the Kirtlington sphenodontid, and the sphenodontians LACM 135616 and LACM 1335531 from the Morrison Formation (S. A., pers. observ.). The region that often bears a mental process is not preserved.

The coronoid process is low and squared, more developed than in Diphydontosaurus and similar in height to those of Planocephalosaurus (Fraser, 1982), Sphenodon, and eilenodontines (including Kaikaifilusaurus; Apesteguía \& Novas, 2003; Apesteguía, 2008). In this aspect, it clearly differs from Clevosaurus (Fraser, 1988) and Ankylosphenodon (Reynoso, 2000). The coronoid bone is not preserved, but the posterior margin of the dentary bears the notch that represents the anterior margin of the mandibular foramen, commonly shared with the surangular.

In Sphenocondor the adductor fossa is longer than high, eye-shaped, and centred ventral to the coronoid process (Figs 2, 3A); it differs from that of most sphenodontians, which is located posterior to the level of the coronoid tip. In Sphenovipera (Reynoso, 2005) the adductor fossa is also located ventral to the coronoid process, but differs from that of Sphenocondor in being oblique rather than horizontal.

The posterior process of the dentary is broken and slightly out of place, but it is rather well preserved and the missing part left a clear mould indicating its size and shape. The process is very long, as much as the long coronoid base. No postdentary bones have been preserved.

\section{Teeth}

There are around 20 preserved teeth in the holotype of Sphenocondor; all of them are acrodont and more or less conical in shape (Fig. 2). As in most sphenodontians, there are represented several dental generations arranged in an anterior-to-posterior sequence, comprising: (1) a successional dentition encompassing at least three teeth (probably four); (2) an alternating hatchling series composed of 15-16 teeth; (3) an additional generation composed of three large teeth uniform in size and shape (Fig. 2).

The anterior-most region is not well preserved. There is a large separated fragment of bone that could be considered as part of the anteromedial symphyseal spur (Figs 2, 4A), or part of a large successional tooth. However, the preservation does not allow certain identification. Behind it follow two strongly recurved and profusely striated successional teeth, the second much taller than the first. They are labiolingually compressed and bear on the labial side a groove or canal that delimits an anterior flange. This trait is also present in juvenile specimens of Godavarisaurus (Evans et al., 2001; Fig. 4B), which also share the general shape and relative position of the pieces. More than one successional tooth in adults is also present in other sphenodontians (Table 2), such as Theretairus (Simpson, 1926) and Sphenovipera (Reynoso, 2005). However, they differ from Sphenocondor in having 'caniniforms' widely separated and rounded in crosssection. The presence in Sphenocondor of anterior flanges in the successional teeth probably represents a derived feature shared with Godavarisaurus.

Posterior to these successional teeth, after a short diastema, begins the hatchling series. The latter teeth are alternated in size, as characteristic for hatchling dentition (Robinson, 1976), and can be divided into three groups according to size (Fig. 2). The anterior group comprises four smooth, small teeth that are almost completely worn down and might have occluded with the maxillary successionals. The second group is composed of five or six well-preserved, conical teeth that are intermediate in size, about twofold the anterior hatchling pieces, and bear sharp cusps relatively unworn. These hatchling teeth might have matched the anterior-most hatchling teeth on the maxilla, explaining the difference in wear with 
Table 2. Number of simultaneous successional teeth in rhynchocephalians

\begin{tabular}{|c|c|c|c|}
\hline Taxon & Ontogenetic stage & Successionals & Notes \\
\hline Sphenocondor & T2-T3 & 2 (posterior) & The last one larger, space enough for 3 anterior \\
\hline Diphydontosaurus & Adult & 5 & 2nd and 5th larger \\
\hline \multirow[t]{2}{*}{ Rebbanasaurus } & Juvenile & 5 & Last 2 larger; \\
\hline & Adult & $2-3$ & The last 2 larger \\
\hline Godavarisaurus & Juvenile and adult & At least $4,5 ?$ & 2nd? and last larger \\
\hline Kirlington sphenodontid & Adult & $2-3$ & The last larger, 'caniniform' \\
\hline \multirow[t]{2}{*}{ Cynosphenodon } & $\mathrm{T} 3-\mathrm{T} 4$ & At least 4 & The last larger \\
\hline & Adult & 1 'caniniform' & Secondary bone obscures anterior teeth \\
\hline Theretairus & Adult & At least 2 & Large, spaced 'caniniforms' \\
\hline Sphenovipera & Adult & At least 3 & Two large, spaced 'caniniforms' \\
\hline \multirow[t]{2}{*}{ Clevosaurus hudsoni } & Immature (T3?), & $\begin{array}{l}3 \text { replacing the } \\
\text { first } 4-5 \mathrm{ht}\end{array}$ & \\
\hline & Adult & 0 & Secondary bone obscure anterior teeth \\
\hline Kaikaifilusaurus avelasi & Juveniles and adults & 0 & Never developed \\
\hline
\end{tabular}

ht, hatchling teeth.
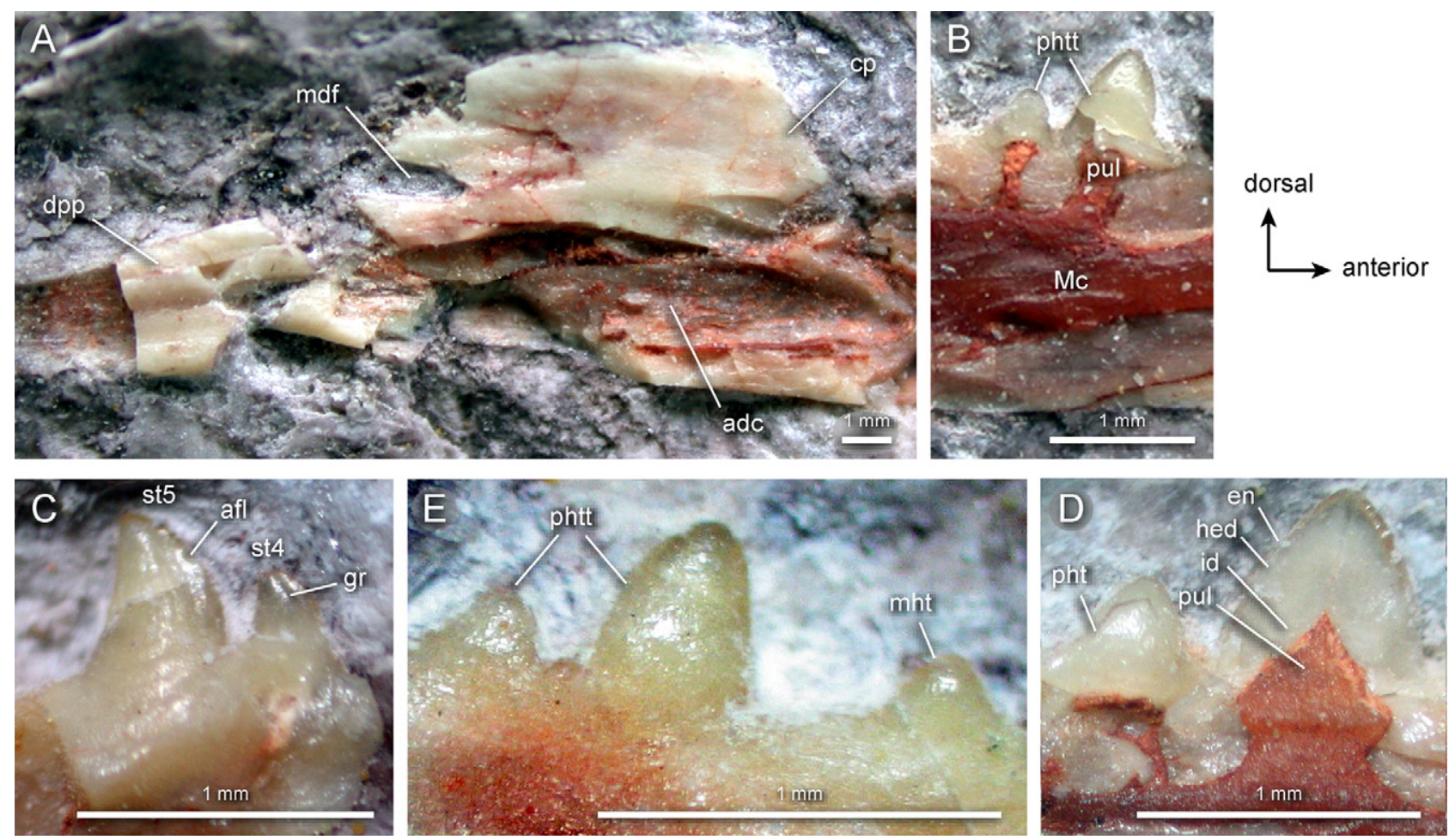

Figure 3. Sphenocondor gracilis gen. et sp. nov., holotype (MPEF-PV 2358), right dentary. A, close-up of coronoid region in lingual view. B, sagittal section of dentary bearing posterior hatchling teeth in lingual view. C, 'caniniform' successional teeth in lingual view. $\mathrm{D}$, internal structure of most posterior hatchling teeth. E, last middle and first posterior hatchling teeth in labial view. Photographs in A, B, C, and D reversed. Abbreviations: adc, adductor fossa; afl, anterior flange; cp, coronoid process; dpp, dentary posterior process; en, enamel; gr, groove; hed, hyaline external dentine; id, internal dentine; Mc, Meckelian canal; mht, middle hatchling tooth; pht, posterior hatchling tooth; phtt, posterior hatchling teeth; pul, pulpar cavity; st4, fourth successional tooth; st5, fifth successional tooth. 
A

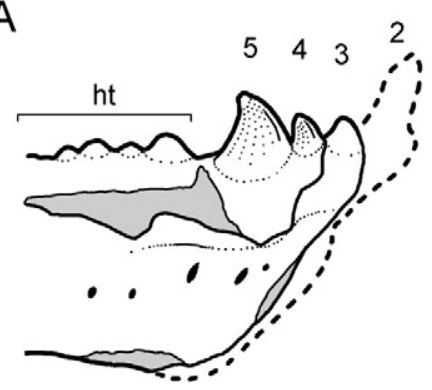

D

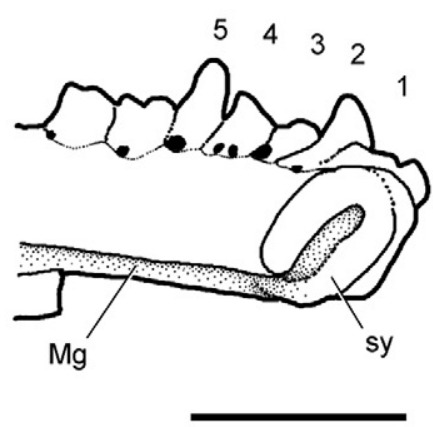

G

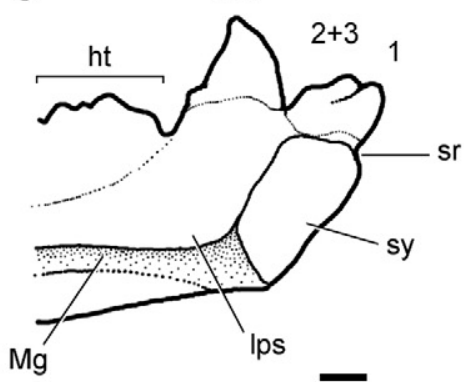

B

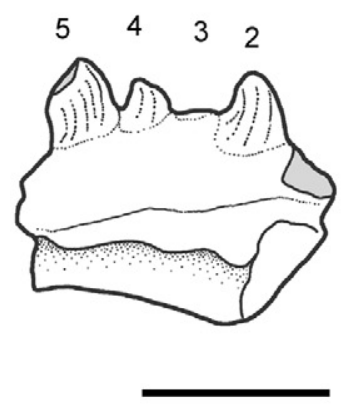

E

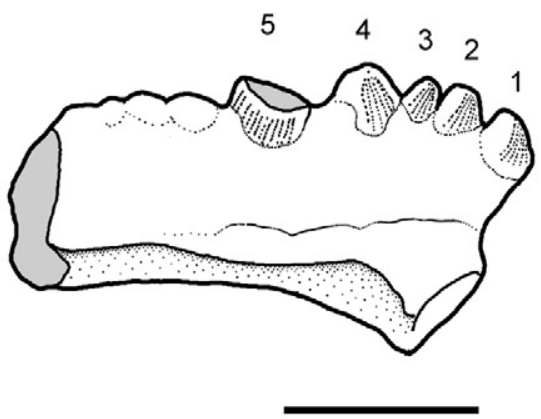

$\mathrm{H}$

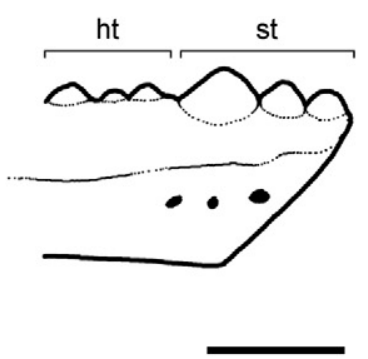

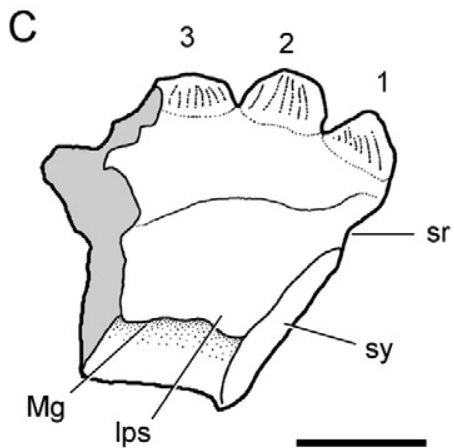

C

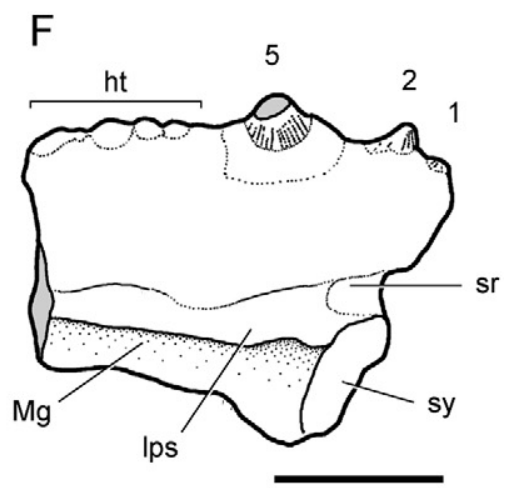

I

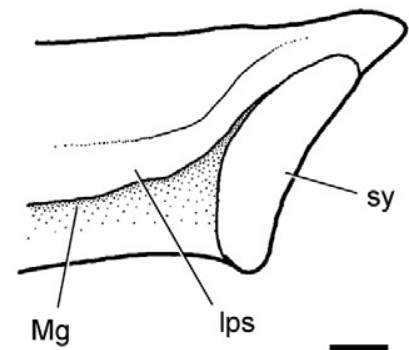

Figure 4. Symphyseal region of the dentary and successional teeth of selected rhynchocephalians. A, Sphenocondor gracilis gen. et sp. nov., holotype (MPEF-PV 2358). B, Godavarisaurus lateefi, juvenile. C, Godavarisaurus lateefi, mature; D, Diphydontosaurus avonis. E, Rebbanasaurus jaini, juvenile. F, Rebbanasaurus jaini, immature. G, Sphenodon punctatus, mature. H, Clevosaurus hudsoni, immature. I, Clevosaurus hudsoni, adult. B, C, E, and F redrawn from Evans et al. (2001:figs 5B, D, 13A, C), C reversed; D redrawn from Whiteside (1986:fig. 28), but reversed; G redrawn from Throckmorton, Hopson \& Parks (1981:fig. 1B), but reversed; H and I redrawn from Fraser (1988:figs 19b, 23b). Abbreviations: 1-5, successional tooth positions; ht, hatchling teeth; lps, postsymphyseal lamina; Mg, Meckelian groove; sr, symphyseal recess; st, successional teeth; sy, symphysis. Scale bars $=1 \mathrm{~mm}$.

respect to the preceding hatchling teeth. The third and most posterior hatchling group comprises six high, conical teeth with rounded walls and devoid of striations. The latter are clearly larger and less worn than the other hatchling teeth, possibly indicating that these larger teeth belong to a younger hatchling generation that developed as the dentary bone grew during early ontogeny. The relative height of these posterior hatchling teeth is similar to those of Sphe- nodontian B (Evans \& Sigogneau-Russell, 1997), with respect to the dentary height below them. The aforementioned size variation in the alternating hatchling series with teeth becoming larger posteriorly is also present in other sphenodontian taxa, such as Planocephalosaurus (Fraser, 1982).

As in other sphenodontians, which are typified by the addition of acrodont teeth at the rear of the jaw that are not replaced during ontogeny (Robinson, 1976), at 
the posterior end of the tooth line of Sphenocondor there is an additional series made up of three badly preserved teeth exposed in labial view; this preservation prevents us from identifying flanges on the lingual surface of these teeth. These additional teeth are conical and sharp, with their bases being about twice as long as the bases of the posterior hatchling teeth. At least on the labial surface, Sphenocondor lacks well-developed flanges on the additional teeth, thus differing from additional teeth in many derived sphenodontians (e.g. Tingitana, Clevosaurus, Homoeosaurus, Kallimodon, Sphenodon). They resemble some of the teeth of Planocephalosaurus, and some of the additional teeth of Godavarisaurus.

The natural breakage in two slabs running diagonally along the jaw allowed us to study the lateral side of the anterior region, the medial side of the posterior region, and the sagittal inner structure of the mid region (Figs 2,3). The posterior hatchling teeth allow the inspection of their respective pulpar cavities (Fig. 3B, D). As the more anterior tooth is not sagittally broken, only part of the pulpar cavity is visible, differing from the following, which sustained a sagittal break. The pulpar cavities are wide in both cases, expanded in the interior of every tooth and narrowing downwards, but remaining open. The pulpar cavities join each other before reaching the upper margin of the Meckelian canal, establishing an oblique ventral connection.

The fifth posterior hatchling tooth is the best to study the inner structure of the teeth (Fig. 6B) because the pulpar cavity of this bulbous tooth is fully exposed by a perfect sagittal section and devoid of further damage. The outer layer of the tooth is formed by a uniform thick layer of enamel that covers the entire dental piece. Under the enamel there is a thick cover of dentine composed by two morphological types. The upper part of the dentine is represented by a hyaline dentine that is thicker in the top of the tooth crown. The lower part of the dentine is thick and whitish. A conspicuous odontoblastic line runs from the enamel base to the upper part of the pulp across the dentine layers. Additionally, numerous radiating lines, the odontoblast prolongations, run across the dentine layer. The pulp cavity is rhomboid in shape and increases its width downwards to reach a maximum at the dorsal margin of the dentary, where it narrows abruptly, separating the main pulp cavity from the dorsal margin of the Meckelian groove.

\section{PHYLOGENETIC ANALYSIS}

In order to assess the evolutionary relationships of Sphenocondor gracilis within Sphenodontia, a parsimony analysis was performed. In light of recent phylogenetic hypotheses of rhynchocephalians, Youngina, the squamatan Pristidactylus, and Gephyrosaurus were used as sphenodontian outgroups to root the recovered optimal topologies. The ingroup taxon sample includes, besides Sphenocondor, most of the taxa previously considered in phylogenetic analyses plus three additional Gondwanan taxa, whose relationships have never been rigorously tested. Most of the characters used in the analysis are based on those of Wu $(1991,1994)$, Sues, Shubin \& Olsen (1994), Reynoso (1996, 1997, 2005), Reynoso \& Clark (1998), Apesteguía \& Novas (2003), and Apesteguía (2008). However, several characters and character states were modified to make more explicit the way they were coded herein. In some cases other states were added to include observed variation within the taxon sample. As many sphenodontians are only known from jaw remains and only a small proportion of characters deal with lower jaw morphology in most published analyses, seven characters of the dentary bone and dentition were added (see Appendix).

The resulting data matrix of 73 characters coded for 26 taxa (see Appendix) was analysed under equally weighted maximum parsimony in TNT v. 1.1 (Goloboff, Farris \& Nixon, 2008a, b), treating multistate characters as unordered. A heuristic search of 500 random-addition sequences followed by tree bisection and reconnection branch swapping (with retention of ten trees per replicate) was performed. Zero-length branches were collapsed following rule 1 of Coddington \& Scharff (1994).The node support was estimated using Bremer-support indices and by 1000 rounds of symmetric resampling, expressed as frequency difference (GC) values (Goloboff et al., 2003).

The analysis yielded 24 most parsimonious trees (MPTs) of 186 steps (consistency index $=0.538$; retention index $=0.751$ ), the reduced strict consensus of which is shown in Figure 5. Sphenodontia (sensu Benton, 1985) was consistently recovered as a monophyletic group, as were also several groupings obtained in previous analyses, including 'derived sphenodontians' (Sphenodontidae sensu Reynoso, 1996, 1997), clevosaurs (Clevosaurus + Brachyrhinodon; Reynoso, 1996; Arantes, Soares \& Schultz, 2009), sapheosaurs (Sapheosaurus + Kallimodon), Opisthodontia (sensu Apesteguía \& Novas, 2003), eilenodontines (Reynoso, 1996; Apesteguía \& Novas, 2003), and a clade formed by Sphenovipera and Theretairus (Reynoso, 2005).

Sphenodontidae Cope, 1869 is an early name created to include Sphenodon alone and later incorporated most fossil allies. However, Sphenodontidae results, under current knowledge, in a vast group and the use of a familiar name to include Clevosaurus and Sphenodon might be misleading. Hence, it is preferred herein to use the informal term 'derived sphenodontians' for this clade. 


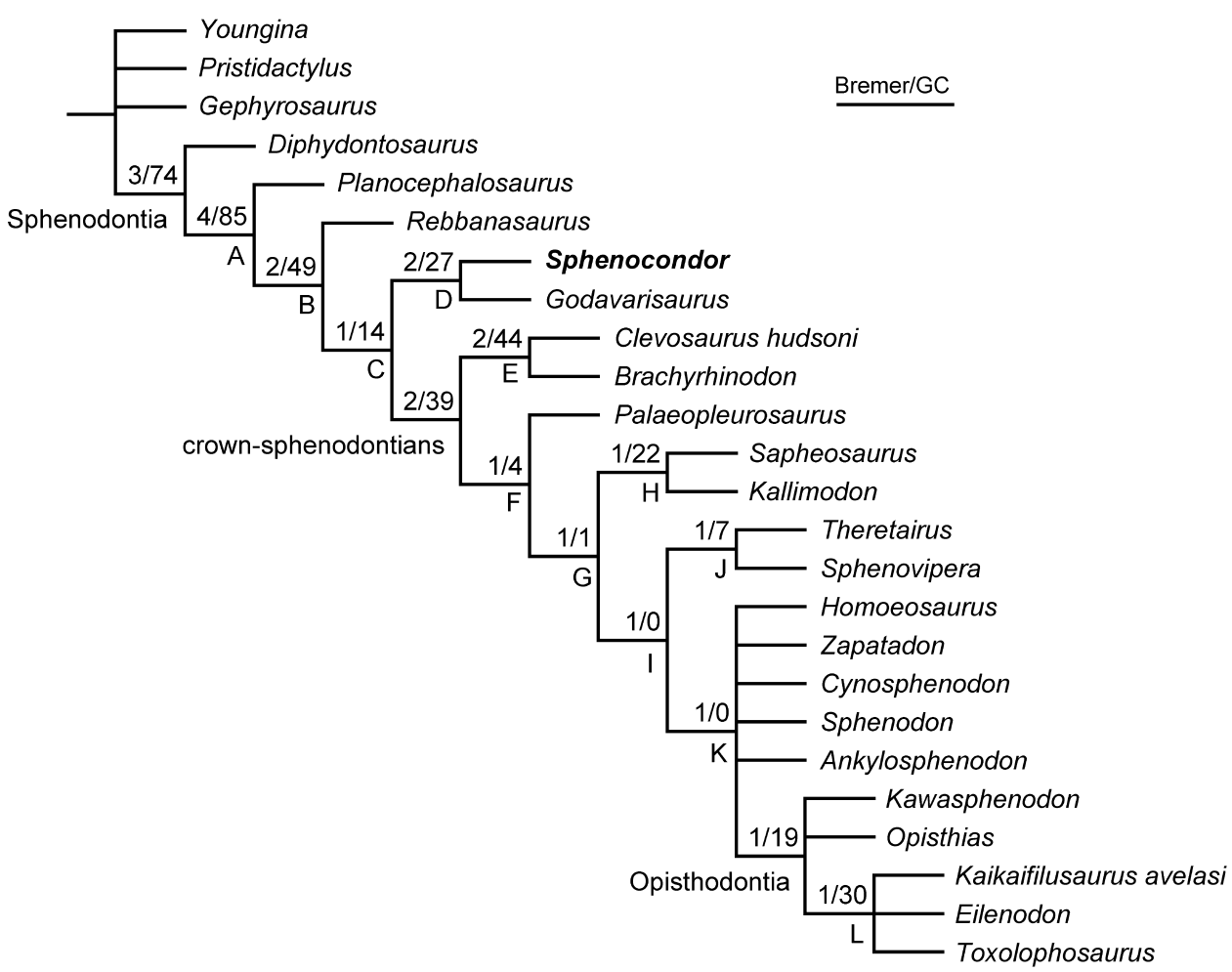

Figure 5. Reduced strict consensus (after removing Pamizinsaurus) of sphenodontian interrelationships from 24 most parsimonious trees of 186 steps showing the phylogenetic position of Sphenocondor gracilis gen. et sp. nov. Bremer support and frequency differences (GC), calculated by symmetric resampling, are indicated above the nodes.

In all MPTs Sphenocondor is placed within Sphenodontia (Fig. 5), a position supported by the presence of additional teeth at the rear of the jaw in the new taxon. Additionally, Sphenocondor lies within a clade of sphenodontians that excludes Diphydontosaurus and Planocephalosaurus because of the presence of a fully acrodont dentition, a large mandibular foramen, a well-developed coronoid process of the dentary, and unribbed hatchling dentition.

Within Sphenodontia, Sphenocondor is consistently depicted as external to the derived sphenodontians (including clevosaurs, Sphenodon, and eilenodontines) because of the absence of derived states regarding wear facets in marginal teeth as well as characters of the successional and additional dentition of the dentary.

All MPTs cluster Sphenocondor in a clade with the Indian Godavarisaurus from the Jurassic Kota Formation. The monophyly of this Gondwanan clade is supported by two synapomorphies regarding the morphology of the dentary teeth, namely, the absence of ridges in posterior additionals (character $59: 0$ ) and the presence of an anterolingual groove in the posterior successionals (character $71: 1$ ) (see Discussion). In addition, Sphenocondor shares with Godavarisaurus the presence of successionals markedly ribbed, the posterior-most of which is relatively large and recurved posteriorly (Evans et al., 2001: figs 13C, D, $14 \mathrm{~A}-\mathrm{D}$ ), but the retention in basal forms of a large number of successionals and, conversely, the reduction of them in derived forms, suggest that several of these features are likely to be plesiomorphic. The purported phylogenetic position of the other Kota sphenodontian, Rebbanasaurus (Evans et al., 2001), is confirmed; it is placed in a more derived position than Diphydontosaurus and Planocephalosaurus and basal to all other sphenodontians.

In the strict consensus of the present analysis, the inter-relationships within recovered groupings of derived sphenodontians are poorly resolved, as in other analyses with somewhat similar taxon sampling (e.g. Reynoso, 2000, 2005). However, this is mainly because of the unstable position of Pamizinsaurus, which might be a consequence of the immature condition of the sole known specimen and its peculiar combination of character states (Reynoso, 1997). Therefore, Pamizinsaurus was excluded from the strict consensus (but not from the analysis), rendering a more resolved topology in the reduced strict consensus (Fig. 5).

In this analysis two forms represent clevosaurs, diagnosed by at least six synapomorphies, emerging 
in a basal position within derived sphenodontians. They are followed in the branching pattern by Palaeopleurosaurus and the clustering of Sapheosaurus and Kallimodon, informally named as sapheosaurs, as in other analyses of sphenodontians (e.g. Apesteguía \& Novas, 2003). As stated above, a clade formed by Sphenovipera and Theretairus is recovered; the purported monophyletic condition of Sphenodontinae (Reynoso \& Clark, 1998) is not corroborated, but the support for the alternative is very weak. The affinities of Homoeosaurus to other sphenodontians are still poorly understood, despite the analysis developed by $\mathrm{Wu}$ (1994); its nested position within eupropalinal sphenodontians (sphenodontines, eilenodontines, and allies) is in conflict with previous hypotheses in that it takes a more basal position within derived sphenodontians (e.g. Reynoso, 1996; Apesteguía \& Novas, 2003). New data on Homeosaurus, or new interpretations of the material, are needed in order to clarify its phylogenetic relationships. Within eupropalinal sphenodontians, the formerly proposed monophyly of both Opisthodontia and Eilenodontinae (Apesteguía \& Novas, 2003; Apesteguía, 2008) is corroborated and well supported (Fig. 5). Additionally, the Late Cretaceous Kawasphenodon appears as an opisthodontian as has been suggested (Apesteguía, 2005). In the reduced strict consensus of this analysis, sphenodontines lack resolution; however, the involved nodes collapsed because of the alternant positions of Cynosphenodon within eupropalinal sphenodontians, including the sister-group relation with Sphenodon obtained in previous published analyses (e.g. Reynoso, 1996; Apesteguía \& Novas, 2003).

Whatever the different positions of poorly understood or conflicting taxa within sphenodontians are, this analysis recovered essentially the same topology as previous studies, with Diphydontosaurus and Planocephalosaurus basal to the remainder sphenodontians, clevosaurs relatively basal within derived sphenodontians, and eupropalinal forms in a derived position, including Sphenodon and eilenodontines (e.g. Reynoso, 1996, 1997; Reynoso \& Clark, 1998; Apesteguía \& Novas, 2003). It is noteworthy that the inclusion of several fragmentary or poorly known taxa, such as Theretairus, Sphenovipera, Kawasphenodon, Rebbannasaurus, Godavarisaurus, and Sphenocondor, with a high amount of missing entries, does not necessarily interfere with the resolution of the optimal topologies as was previously suggested (Reynoso, 2005). Instead, the amount of conflict regarding character distribution amongst derived sphenodontians and homoplasy levels appear to be pivotal in the degree of internal resolution within the clade, supporting the overall inclusion of incomplete taxa in broad phylogenetic analyses (Kearney, 2002; Wiens, 2003, 2005).

\section{DISCUSSION}

Based on the results of the phylogenetic analysis (Fig. 5), Sphenocondor is included in Sphenodontia and shares with other members the presence of acrodont teeth, a deep and wide Meckelian groove (and the related lack of ossified splenial bone), a long posterior process and a well-developed coronoid process of the dentary, and dental regionalization including successional, alternate hatchling, and additional teeth. Sphenocondor represents a key taxon for understanding the evolution of rhynchocephalians in southern continents, breaking a vast gap in the South American record that extended from the Upper Triassic to the Lower Cretaceous.

\section{ONTOGENETIC STAGE AND DENTITION DEVELOPMENT}

Sphenodon is the sole rhynchocephalian for which reliable developmental data are available (e.g. Howes \& Swinnerton, 1901; Rieppel, 1992) and, hence, it is almost invariantly used as a model in assessing the ontogenetic stage of fossil forms (e.g. Evans \& Sigogneau-Russell, 1997; Reynoso, 2003). However, it has been noted that Sphenodon is not representative of rhynchocephalians regarding skull and tooth morphology (Jones, 2008, 2009); furthermore, during its ontogeny, the skull of Sphenodon undergoes important changes that partially reflect differences between basal and derived taxa (Jones, 2008). Therefore, ontogenetic assessments derived from comparisons to Sphenodon must be considered with caution. Concerning fossil forms, information on ontogenetic variation is sparse and, with some exceptions (Fraser, 1988; Reynoso, 2003), insufficiently documented. Data on this issue provided by Sphenocondor are discussed below.

The presence of at least two well-developed anterior successional teeth, the second larger, the marked alternation in size of the 16 middle teeth (four worn anterior ones, six middle ones of intermediate size, and the six posterior ones, larger and relatively unworn), and the presence of three large posterior additionals of uniform size in Sphenocondor, suggest that it might represent a juvenile individual comparable to the T2 and T3 stages of Sphenodon as defined by Harrison (1901) and Robinson (1976). This corresponds to an individual of a few months after hatchling. Alternatively, if the posterior six larger teeth of the alternating series are considered anterior additionals that retained a hatchling morphology (Apesteguía, 2008), then the total count of additional teeth rises to nine, and the dentition pattern more closely resembles that of a Sphenodon T4 stage or even a young adult. The size range of Sphenocondor is not known; however, the dentary of Sphenocondor 
(c. $24 \mathrm{~mm}$ ) matches well with that of Sphenodon T3-T4 juvenile stages (head length of 25-35 mm).

Despite the alleged immaturity of the Sphenocondor holotype, its dentary bears all the tooth types present in young adults of most sphenodontians including Sphenodon (Harrison, 1901; Robinson, 1976). The complete dentition pattern from front to back includes successional-, alternate hatchling-, and additional teeth. These constitute a valuable data set and allow meaningful comparisons to other sphenodontian taxa, adding value to the taxonomical entity of Sphenocondor. It is noteworthy that a T2 or T3 stage of Sphenodon does not differ markedly from a young adult individual in the sort and amount of information that they offer (Harrison, 1901; Reynoso, 2003).

In most sphenodontian taxa, the additional teeth are the major components of the adult dentition, or even the only ones as in clevosaurs or eilenodontines (Fraser, 1988; Apesteguía \& Novas, 2003), although basal taxa appear to preserve successional and hatchling teeth during adulthood together with a relatively lower number of morphologically simple additionals (Fraser, 1982, 1986; Whiteside, 1986; Evans et al., 2001). Sphenocondor fits well the latter pattern of dentition and thus, its apparent immature condition in comparison to Sphenodon might be interpreted as a sign of primitiveness rather than youth; unfortunately, ontogenetic data on Sphenocondor to resolve this issue are lacking at present.

\section{SUCCESSIONALS}

The presence of 'caniniform' successional teeth in sphenodontians has been considered of great systematic value by some authors (Gauthier et al., 1988; Reynoso, 1996, 2003, 2005). Fully grown adults of Sphenodon apparently retain a single successional tooth ('caniniform') in the dentary, but adults of basal sphenodontians, such as Diphydontosaurus, Planocephalosaurus, and Godavarisaurus, show at least four or five successionals in the anterior portion of the jaw (Fraser, 1986; Whiteside, 1986; Evans et al., 2001). It is noteworthy that immature individuals of several fossil sphenodontians appear to have a higher count of successionals than fully grown adults; for instance, juveniles of Rebbanasaurus bear up to five successional teeth, whereas adult specimens have only two or three (Evans et al., 2001). These ontogenetic changes are more striking in Clevosaurus, in which immature individuals show at least three uniform-sized successionals that in the adult are either absent or completely obscured by secondary bone (Fraser, 1988). In addition, the successional series usually exhibits some degree of heterodonty, in which one or two posterior successionals are frequently larger than the other teeth (Evans, 1992; Evans et al., 2001; Reynoso, 2003, 2005). The two posterior successionals of Sphenocondor closely match those of immature Godavarisaurus in their peculiar morphology as well as in relative size (Evans et al., 2001); in view of the purported phylogenetic sistergroup relation between Sphenocondor and Godavarisaurus, it is possible that Sphenocondor might have had up to three other successionals further anteriorly.

In some taxa successionals hypertrophy and develop into 'caniniforms' as in Sphenodon (e.g. Robinson, 1976; Reynoso, 2005). The presence of successional teeth in adult sphenodontians appears to be a plesiomorphic condition within the group and is not necessary linked to the development of 'caniniforms' (Whiteside, 1986; Evans et al., 2001). Besides, it has been acknowledged that tooth hypertrophy is variable within species and is scattered amongst lizard groups (Borsuk-Bialynicka, 1996). In consideration of the foregoing it is evident that new data and further analyses are needed to clarify some aspects of the evolution of successional dentition in sphenodontians; chief amongst them is the homology of sphenodontian 'caniniforms' and its systematic value.

\section{BIOGEOGRAPHY}

The oldest rhynchocephalians are Late Triassic, including Euramerican basal forms such as Diphydontosaurus (Whiteside, 1986), Planocephalosaurus (Fraser, 1982), Paleollanosaurus (Heckert, 2004), and Whitakersaurus (Heckert et al., 2008), as well as clevosaurs and related forms (e.g. Brachyrhinodon, Polysphenodon) also from Europe (e.g. Fraser, 1988; Fraser \& Benton, 1989; Evans \& Kermack, 1994) and North America (Fraser, 1993; Heckert, 2004). Accordingly, Triassic Gondwanan rhynchocephalians only include clevosaurs, with records from Brazil (e.g. Ferigolo, 1999; Bonaparte \& Sues, 2006) and India (Evans \& Jones, 2010). Except for the remains of the controversial Sigmala and Pelecymala (Fraser, 1986), the record shows only two types of rhynchocephalians: basal taxa and clevosaurs or closely related forms, indicating an early split of the main sphenodontian lineages.

The Jurassic rhynchocephalian record shows, in addition to clevosaurs and basal forms, a wealth of diversified and specialized sphenodontians, the vast majority of findings being from Laurasian landmasses, with only a few records from Gondwana. Actually, our understanding of the evolution of the Jurassic Rhynchocephalia is based almost exclusively on their northern record. Early Jurassic findings from Laurasia include basal forms from the UK (e.g. Gephyrosaurus; Evans, 1980) and clevosaurs from the UK (e.g. Evans \& Kermack, 1994; Säilä, 2005), North 


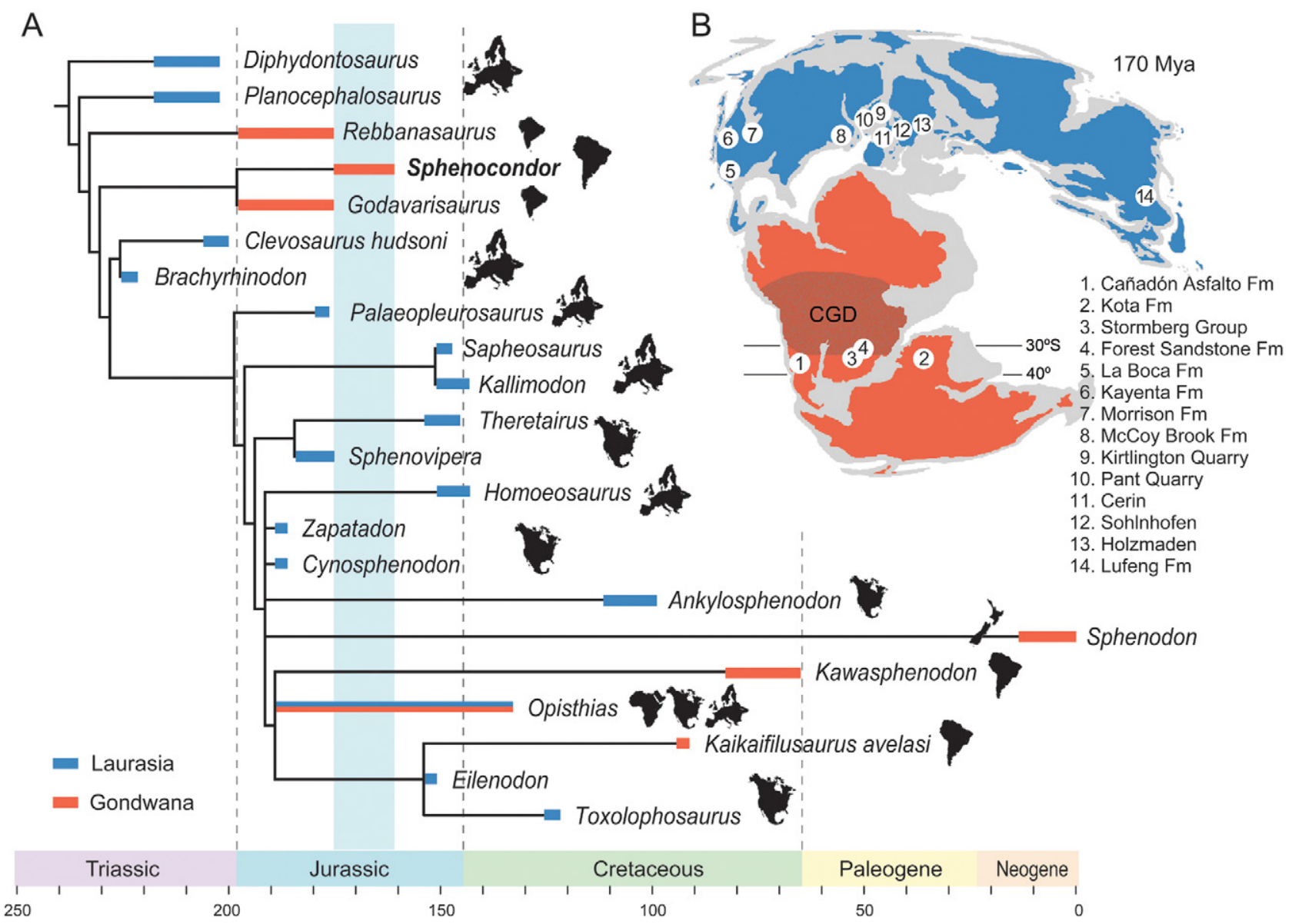

Figure 6. A, time-tree of rhynchocephalians with the latest possible branching points for lineages, based on the reduced strict consensus of Figure 5. The Middle Jurassic is depicted by a shaded bar. B, palaeobiogeographical distribution of Jurassic rhynchocephalians. Palaeogeographical reconstruction modified from Blakey (2008), using the timescale of Gradstein et al. (2004). Abbreviation: CGD, Central Gondwanan Desert.

America (e.g. Reynoso, 1993; Sues et al., 1994), and China (Wu, 1994; Jones, 2006). Additionally, the diverse sphenodontians from the lower member of the La Boca Formation of Mexico (now considered to be Early Jurassic; Clark et al., 1994; Reynoso, 1996, 2005; Rubio-Cisneros \& Lawton, 2011) and the highly derived marine Palaeopleurosaurus from Germany (Carroll, 1985) show that rhynchocephalians were well diversified by then. Conversely, the Early Jurassic records from southern landmasses are restricted to the basal sphenodontians from India (Rebbanasaurus and Godavarisaurus; Evans et al., 2001) and putative clevosaurs from South Africa (Sues \& Reisz, 1995) and Zimbabwe (Gow \& Raath, 1977).

The Middle Jurassic record is extremely scarce worldwide so far, consisting of a few fragmentary fossils of uncertain taxonomic affinities from the UK (e.g. Evans, 1992). The discovery of Sphenocondor, the first Gondwanan Middle Jurassic rhynchocephalian, and the resulting phylogenetic analysis suggests an early, or basal, Triassic diversification including plesiomorphic forms and clevosaurs, whose descendants would later reach a Pangaean distribution. After this initial diversification, our results highlight the occurrence of a second sphenodontian radiation during the Early Jurassic, in which two distinct, geographically separated lineages (i.e. Euramerica and South Gondwana) diversified and replaced most of the early forms (e.g. clevosaurs) by the Middle Jurassic (Fig. 6). It is noteworthy that the Jurassic Euramerican and South Gondwanan forms are mostly restricted to Dry Subtropical (winter wet) belts (i.e. the Central North American-Northern Tethys, in Laurasia, and the $30^{\circ}$ to $40^{\circ}$ South Gondwanan strip; Fig. $6 \mathrm{~B}$ ), suggesting palaeoclimatic constraints in the geographical distribution of Early-Middle Jurassic sphenodontians. Under this scenario, the Central Gondwanan Desert arose as an extensive barrier that isolated southern Gondwana from the equatorial region and Laurasia in the Jurassic (Fig. 6B). 
The recognition of a probably endemic Southern Gondwanan clade (i.e. Sphenocondor + Godavarisaurus) that originated during the Early Jurassic and evolved isolated during the Middle Jurassic from the main radiation of Sphenodontia mirrors the pattern recovered for other tetrapod groups such as Eusauropoda (e.g. Remes et al., 2009). Eusauropod dinosaurs from the Cañadón Asfalto (Patagonia), Kota (India), Elliot and Clarens (Zimbabwe), Tendaguru (Tanzania), and Hanson (Antarctica) formations depict a panorama similar to that of rhynchocephalians, in which Early Jurassic Pangaean distributions were replaced by Middle Jurassic partially endemic forms. The hypothesis of increased endemism in response to the initial breakup of Pangaea, formerly furnished by data provided by Jurassic archosaurs (e.g. Bonaparte, 1986), gains support from the new evidence offered herein. However, as pointed out previously (Rauhut \& López-Arbarello, 2008), this scenario is hard to test when it is largely based on findings from the Northern Hemisphere. The information provided herein by rhynchocephalians helps us to have a glimpse at the evolutionary path that this peculiar group of lepidosaurs underwent.

\section{CONCLUSIONS}

Sphenocondor represents the first rhynchocephalian for the Jurassic of South America and one of the few Middle Jurassic records of the group worldwide. The new taxon exhibits some uncommon features in the dentary, including an adductor fossa that is centred under the coronoid process. Additionally, the dentition shows some peculiar traits such as a basally constricted hatchling dentition organized in three different groups according to size, as well as the presence of two strongly recurved and profusely striated successional teeth bearing a grooved anterior flange. These successional teeth clearly differ from those of Theretairus and Sphenovipera in the lack of interdental space, amongst other features.

The morphological evidence provided by Sphenocondor allows us to discuss some aspects of the evolution of successional dentition in rhynchocephalians. The main results indicate that within the successional series typically there exists a size and shape heterodonty from the anterior to posterior teeth. Additionally, the persistence of several successional teeth in adult sphenodontians emerges as a plesiomorphic feature within the group, which might not be connected to the development of 'caniniforms'.

The phylogenetic analysis places Sphenocondor as a relatively basal form within Sphenodontia, clustered with the Indian Godavarisaurus from the Jurassic Kota Formation. This probably endemic Southern Gondwanan clade, as also expressed by other tetrapod groups (e.g. Eusauropoda), gives support to the hypothesis of increased endemism in response to the initial breakup of Pangaea.

A further explanation for this observed pattern arises from the restriction of the Jurassic Euramerican and South Gondwanan forms to the Dry Subtropical (winter wet) climatic belts, both separated by the extensive Central Gondwanan Desert. The latter might have constituted an effective barrier for the dispersal of some groups of terrestrial organisms.

\section{ACKNOWLEDGEMENTS}

We thank Eduardo Ruigómez (MEF) for curatorial assistance regarding the fossil material. We thank the MEF team (L. Canessa, M. Cárdenas, R. Cúneo, A. Lecuona, P. Puerta, and J. Sterli) for help during fieldwork. We thank Dr Cynthia Corbitt for editorial comments on the manuscript. We are grateful to the Willi Hennig Society for the free internet access to the TNT software package. This work was supported by the project 'Paleontological Exploration of Patagonia' (Fundación Antorchas and University of Louisville) and NSF grants DEB-0946430 and DEB 1068089 to G. W. R. Additional support was provided by a grant of the Agencia de Promoción Científica y Tecnológica (PICT 1756/06).

\section{REFERENCES}

Abramoff MD, Magalhaes PJ, Ram SJ. 2004. Image processing with ImageJ. Biophotonics International 11: 36-42.

Apesteguía S. 2005. A Late Campanian sphenodontid (Reptilia, Diapsida) from northern Patagonia. Comptes Rendus Palevol 4: 663-669.

Apesteguía S. 2008. Esfenodontes (Reptilia, Lepidosauria) del Cretácico Superior de Patagonia: anatomía y filogenia. Unpublished PhD Thesis, Universidad Nacional de La Plata.

Apesteguía S, Novas FE. 2003. Large Cretaceous sphenodontian from Patagonia provides insight into lepidosaur evolution in Gondwana. Nature 425: 609-612.

Arantes BA, Soares MB, Schultz CL. 2009. Clevosaurus brasiliensis (Lepidosauria, Sphenodontia) do Triássico Superior do Rio Grande do Sul: anatomia pós-craniana e relações filogenéticas. Revista Brasileira De Paleontologia 12: 43-54.

Benton MJ. 1985. Classification and phylogeny of the diapsid reptiles. Zoological Journal of the Linnean Society 84: 97-164.

Blakey RC. 2008. Gondwana paleogeography from assembly to breakup - a 500 million year odyssey. In: Fielding CR, Frank TD, Isbell JL, eds. Resolving the Late Paleozoic Ice Age in Time and Space. Geological Society of America Special Paper 441, 1-28.

Bonaparte JF. 1979. Dinosaurs: a Jurassic assemblage from Patagonia. Science 205: 1377-1379. 
Bonaparte JF. 1986. Les Dinosaures (Carnosaures, Allosauridés, Sauropodes, Cétiosauridés) du Jurassique moyen de Cerro Cóndor (Chubut, Argentine). Annales De Paléontologie 72: 326-386.

Bonaparte JF, Sues H-D. 2006. A new species of Clevosaurus (Lepidosauria: Rhynchocephalia) from the Upper Triassic of Rio Grande do Sul, Brazil. Palaeontology 49: 917-923.

Borsuk-Bialynicka M. 1996. The Late Cretaceous lizard Pleurodontagama and the origin of tooth permanency in Lepidosauria. Acta Palaeontologica Polonica 41: 231-252.

Cabaleri N, Volkheimer W, Silva Nieto D, Armella C, Cagnoni M, Hauser N, Matteini M, Pimentel MM. 2010. $\mathrm{U}-\mathrm{Pb}$ ages in zircons from Las Chacritas and Puesto Almada members of the Jurassic Cañadón Asfalto Formation, Chubut Province, Argentina. Extended Abstracts VII South American Symposium on Isotope Geology (CD-ROM, digital only). Brasilia, Brazil, 190-193.

Carroll RL. 1977. The origin of lizards. In: Andrews S, Miles R, Walker A, eds. Problems in vertebrate evolution. London and New York: Academic Press, 359-396.

Carroll RL. 1985. A pleurosaur from the Lower Jurassic and the taxonomic position of the Sphenodontida. Palaeontographica, Abteilung A 189: 1-28.

Clark JM, Montellano M, Hopson J, Hernandez R, Fastovsky DE. 1994. An Early or Middle Jurassic tetrapod assemblage from the La Boca Formation, northeastern Mexico. In: Fraser NC, Sues HD, eds. In the shadow of the dinosaurs: Early Mesozoic tetrapods. Cambridge: Cambridge University Press, 295-302.

Cocude-Michel M. 1963. Les rhynchocéphales et les sauriens des calcaires lithographiques (Jurassique Supérieur) d'Europe occidentale. Nouvelles Archives Du Muséum d'Histoire Naturelle De Lyon 7: 1-187.

Coddington J, Scharff N. 1994. Problems with zero-length branches. Cladistics 10: 415-423.

Cope ED. 1869. Synopsis of the extinct Batrachia, Reptilia and Aves of North America. Transactions of the American Philosophical Society, Philadelphia 14: 1-252.

Cuneo R, Bowring S. 2010. Dataciones geocronológicas preliminares en la Cuenca Cañadón Asfalto, Jurásico de Chubut, Argentina. In: Artabe A, Tortello F eds. Actas $X$ Congreso Argentino de Paleontología y Bioestratigrafía $y$ VII Congreso Latinoamericano de Paleontología. La Plata, Argentina: Museo de La Plata, 153.

Daugherty CH, Cree A, Hay JM, Thompson MB. 1990. Neglected taxonomy and continuing extinctions of tuatara (Sphenodon). Nature 347: 177-179.

Escapa IH, Sterli J, Pol D, Nicoli L. 2008. Jurassic tetrapods and flora of Cañadón Asfalto Formation in Cerro Cóndor area, Chubut Province. Revista De La Asociación Geológica Argentina 63: 613-624.

Estes R. 1983. The fossil record and early distribution of lizards. In: Rhodin A, Miyata K, eds. Studies in herpetology and evolutionary biology. Essays in honor of Ernest Edward Williams. Cambridge: Museum of Comparative Zoology, Harvard University Press, 365-398.

Evans SE. 1980. The skull of a new eosuchian reptile from the Lower Jurassic of South Wales. Zoological Journal of the Linnean Society 70: 203-264.

Evans SE. 1984. The classification of the Lepidosauria. Zoological Journal of the Linnean Society 82: 87-100.

Evans SE. 1988. The early history and relationships of the Diapsida. In: Benton MJ, ed. The phylogeny and classification of the tetrapods, Vol. 1. Oxford: Clarendon Press, 221260.

Evans SE. 1992. A sphenodontian (Reptilia: Lepidosauria) from the Middle Jurassic of England. Neues Jahrbuch für Mineralogie, Geologie Und Palaeontologie Mittelhungen 8: 449-457.

Evans SE, Jones MEH. 2010. The origin, early history and diversification of lepidosauromorph reptiles. In: Bandyopadhyay S, ed. New aspects of Mesozoic biodiversity, lecture notes in earth sciences 132. Berlin, Heidelberg: SpringerVerlag, 27-44.

Evans SE, Kermack KA. 1994. Assemblages of small terrestrial tetrapods from the Early Jurassic of Britain. In: Fraser NC, Sues H-D, eds. In the shadow of the dinosaurs: Early Mesozoic tetrapods. Cambridge: Cambridge University Press, 271-283.

Evans SE, Prasad GVR, Manhas BK. 2001. Rhynchocephalians (Diapsida: Lepidosauria) from the Jurassic Kota Formation of India. Zoological Journal of the Linnean Society 133: 309-334.

Evans SE, Sigogneau-Russell D. 1997. New sphenodontians (Diapsida: Lepidosauria: Rhynchocephalia) from the Early Cretaceous of North Africa. Journal of Vertebrate Paleontology 17: 45-51.

Ferigolo J. 1999. South American first record of a sphenodontian (Lepidosauria, Rhynchocephalia) from Late Triassic-Early Jurassic of Rio Grande do Sul State, Brazil. In: Leanza HA, ed. Abstracts VII International Symposium on Mesozoic terrestrial ecosystems. Buenos Aires: Museo Argentino de Ciencias Naturales, 24-25.

Figari EG, Courtade SF. 1993. Evolución tectosedimentaria de la Cuenca de Cañadón Asfalto, Chubut, Argentina. In: Vergara Oroño A, ed. Actas XII Congreso Geológico Argentino y II Congreso de Exploración de Hidrocarburos 1. Mendoza, Argentina: Vergara Oroño A, 66-77.

Figari EG, Courtade SF, Constantini LA. 1996. Stratigraphy and tectonics of Cañadón Asfalto Basin, Lows of Gastre and Gan Gan, North of Chubut Province, Argentina. GeoResearch Forum 1-2: 359-368.

Fraser NC. 1982. A new rhynchocephalian from the British Upper Triassic. Palaeontology 25: 709-725.

Fraser NC. 1986. New Triassic sphenodontids from SouthWest England and a review of their classification. Palaeontology 29: 165-186.

Fraser NC. 1988. The osteology and relationships of Clevosaurus (Reptilia: Sphenodontida). Philosophical Transactions of the Royal Society B 321: 125-178.

Fraser NC. 1993. A new sphenodontian from the early Mesozoic of England and North America: implications for correlating early Mesozoic continental deposits. New Mexico Museum of Natural History and Science, Bulletin 3: 135139. 
Fraser NC, Benton MJ. 1989. The Triassic reptiles Brachyrhinodon and Polysphenodon and the relationships of the sphenodontids. Zoological Journal of the Linnean Society 96: 413-445.

Gaetano L, Rougier GW. 2011. New materials of Argentoconodon fariasorum (Mammaliaformes, Triconodontidae) from the Jurassic of Argentina and its bearing on triconodont phylogeny. Journal of Vertebrate Paleontology 31: 829-843.

Gauthier JA, Estes R, De Queiroz K. 1988. A phylogenetic analysis of the Lepidosauromorpha. In: Estes R, Pregill G, eds. Phylogenetic relationships of the lizard families: essays commemorating Charles M. Camp. Stanford, CA: Stanford University Press, 15-98.

Gilmore CW. 1909. A new rhynchocephalian reptile from the Jurassic ofWyoming, with notes on the fauna of Quarry 9. Proceedings of the US National Museum 37: 35-42.

Goloboff PA, Farris S, Källersjö M, Oxelmann B, Ramírez M, Szumik C. 2003. Improvements to resampling measures of group support. Cladistics 19: 324-332.

Goloboff PA, Farris S, Nixon K. 2008a. TNT, a free program for phylogenetic analysis. Cladistics 24: 774-786.

Goloboff PA, Farris S, Nixon K. 2008b. TNT: tree analysis using new technology, v. 1.1 (Willi Hennig Society Edition). Program and documentation available at: http://www.zmuc. $\mathrm{dk} /$ public/phylogeny/tnt

Gow CE, Raath MA. 1977. Fossil vertebrate studies in Rhodesia: sphenodontid remains from the Upper Triassic of Rhodesia. Palaeontologia Africana 20: 121-122.

Gradstein FM, Ogg JG, Smith AG, Bleeker W, Lourens LJ. 2004. A new Geologic Time Scale, with special reference to Precambrian and Neogene. Episodes 27: 83-100.

Günther A. 1867. Contribution to the anatomy of Hatteria (Rhynchocephalus, Owen). Philosophical Transactions of the Royal Society of London 157: 595-629.

Harrison HS. 1901. Development and succession of the teeth in Hatteria punctata. Quarterly Journal of Microscope Science (N.S.) 44: 161-213.

Heckert AB. 2004. Late Triassic microvertebrates from the lower Chinle Group (Otischalkian-Adamanian: Carnian) southwestern USA. New Mexico Museum of Natural History and Science, Bulletin 27: 1-170.

Heckert AB, Lucas SG, Rinehart LF, Hunt AP. 2008. A new genus and species of sphenodontian from the Ghost Ranch Coelophysis Quarry (Upper Triassic: Apachean), Rock Point Formation, New Mexico, USA. Palaeontology 51: 827-845.

Howes GB, Swinnerton HH. 1901. On the development of the skeleton of the Tuatara, Sphenodon punctatus; with remarks on the egg, hatching, and on the hatched young. Transactions of the Zoological Society of London 16: 1-74.

Huene F. 1910. Über einen echten rhynchocephalen aus der Trias von Elgin, Brachyrhinodon taylori. Neues Jahrbuch Für Mineralogie, Geologie Und Paläeontologie 1910: 29-62.

Jones MEH. 2006. The Early Jurassic clevosaurs from China (Diapsida: Lepidosauria). In: Harris JD, Lucas S, Kirkland J, Milner ARC, eds. The Triassic/Jurassic terrestrial transition. Albuquerque, NM: New Mexico Museum of Natural History and Science Bulletin, 548-562.
Jones MEH. 2008. Skull shape and feeding strategy in Sphenodon and other Rhynchocephalia (Diapsida: Lepidosauria). Journal of Morphology 269: 945-966.

Jones MEH. 2009. Dentary tooth shape in Sphenodon and its fossil relatives (Diapsida: Lepidosauria: Rhynchocephalia). Frontiers of Oral Biology 13: 9-15.

Jones MEH, Tennyson AJD, Worthy JP, Evans SE, Worthy TH. 2009. A sphenodontine (Rhynchocephalia) from the Miocene of New Zealand and paleobiogeography of the tuatara (Sphenodon). Proceedings of the Royal Society B: Biological Sciences 276: 1385-1390.

Kearney M. 2002. Fragmentary taxa, missing data, and ambiguity: mistaken assumptions and conclusions. Systematic Biology 51: 369-381.

Musacchio EA, Beros C, Pujana I. 1990. Microfósiles continentales del Jurásico y el Cretácico en Chubut y su contribución a la bioestratigrafia de la Cuenca del Golfo San Jorge, Argentina. In: Volkheimer W, ed. Bioestratigrafía de los Sistemas Regionales del Jurásico y el Cretácico de América del Sur, Vol. 2. Mendoza: CRICYT, 355-383.

Nopsca F. 1928. The genera of reptiles. Palaeobiology 1: $163-188$.

Page R, Ardolino A, Barrio RE, Franchi M, Lizuain A, Page S, Nieto DS. 1999. Estratigrafía del Jurásico y Cretácico del Macizo de Somún Curá, Provincias de Río Negro y Chubut. In: Caminos R, ed. Geología argentina. Buenos Aires: Subsecretaría de Minería de la Nación, 460488.

Pol D, Rauhut OWM, Becerra MG. 2011. A Middle Jurassic heterodontosaurid dinosaur from Patagonia and the evolution of heterodontosaurids. Die Naturwissenschaften 98: 369-379.

Proserpio CA. 1987. Descripción geológica de la Hoja 44 e, Valle General Racedo, Provincia del Chubut. Dirección Nacional De Minería Y Geología, Boletín 201: 1-102.

Rasmussen TE, Callison G. 1981. A new herbivorous sphenodontid (Rhynchocephalia: Reptilia) from the Jurassic of Colorado. Journal of Paleontology 55: 1109-1116.

Rauhut OWM. 2005. Osteology and relationships of a new theropod dinosaur from the Middle Jurassic of Patagonia. Palaeontology 48: 87-110.

Rauhut OWM, López-Arbarello A. 2008. Archosaur evolution during the Jurassic: a southern perspective. Revista De La Asociación Geológica Argentina 63: 557-585.

Rauhut OWM, Martin T, Ortiz-Jaureguizar E, Puerta P. 2002. A Jurassic mammal from South America. Nature 416: 165-168.

Remes K, Ortega F, Fierro I, Joger U, Kosma R, Ferrer JMM, Ide OA, Maga A. 2009. A new basal sauropod dinosaur from the Middle Jurassic of Niger and the early evolution of Sauropoda. PLoS ONE 4: e6924: 1-13.

Reynoso VH. 1993. A sphenodontid assemblage from the Early-Mid Jurassic deposits of Huizachal Canyon, Tamauplipas, Mexico. Journal of Vertebrate Paleontology 13: 54A.

Reynoso VH. 1996. A Middle Jurassic Sphenodon-like sphenodontian (Diapsida:Lepidosauria) from Huizachal Canyon, Tamaulipas, México. Journal of Vertebrate Paleontology 16: 210-221. 
Reynoso VH. 1997. A 'beaded' sphenodontian (Diapsida: Lepidosauria) from the Early Cretaceous of central Mexico. Journal of Vertebrate Paleontology 17: 52-59.

Reynoso VH. 2000. An unusual aquatic sphenodontian (Reptilia: Diapsida) from the Tlayua Formation (Albian), Central Mexico. Journal of Paleontology 74: 133-148.

Reynoso VH. 2003. Growth patterns and ontogenetic variation of the teeth and jaws of the Middle Jurassic sphenodontian Cynosphenodon huizachalensis (Reptilia: Rhynchocephalia). Canadian Journal of Earth Sciences 40: 609-619.

Reynoso VH. 2005. Possible evidence of a venom apparatus in a Middle Jurassic sphenodontian from the huizachal red beds of Tamaulipas, Mexico. Journal of Vertebrate Paleontology 25: 646-654.

Reynoso VH, Clark JM. 1998. A dwarf sphenodontian from the Jurassic La Boca Formation of Tamaulipas, México. Journal of Vertebrate Paleontology 18: 333-339.

Rieppel O. 1992. The skull in a hatchling of Sphenodon punctatus. Journal of Herpetology 26: 80-84.

Robinson PL. 1973. A problematic reptile from the British Upper Triassic. Journal of the Geological Society of London 129: $457-479$.

Robinson PL. 1976. How Sphenodon and Uromastix grow their teeth and use them. In: Bellairs AA, Box B, eds. Morphology and biology of reptiles. London: Academic Press, 43-64.

Romer AS. 1956. Osteology of the reptiles. Chicago, IL: University of Chicago Press.

Rougier GW, Garrido A, Gaetano L, Puerta P, Corbitt C, Novacek MJ. 2007b. A new triconodont from South America. American Museum Novitates 3580: 1-17.

Rougier GW, Martinelli AG, Forasiepi AM, Novacek MJ. 2007a. New Jurassic mammals from Patagonia, Argentina: a reappraisal of australosphenidan morphology and interrelationships. American Museum Novitates 3566: 1-54.

Rubio-Cisneros II, Lawton TF. 2011. Detrital zircon U-Pb ages of sandstones in continental red beds at Valle de Huizachal, Tamaulipas, NE Mexico: record of Early-Middle Jurassic arc volcanism and transition to crustal extension. Geosphere 7: 159-170.

Säilä LK. 2005. A new species of the sphenodontian reptile Clevosaurus from the Lower Jurassic of South Wales. Palaeontology 48: 817-831.

Silva Nieto DG, Cabaleri NG, Salani FM, Gonzales Díaz E, Coluccia A. 2002. Hoja Geológica 4368-27 Cerro Cóndor, provincia de Chubut. Buenos Aires: Instituto de Geología y Recursos Minerales, Servicio Geológico Minero Argentino.

Simpson GG. 1926. American terrestrial Rhynchocephalia. American Journal of Science 5: 12-16.

Smith JB, Dodson P. 2003. A proposal for a standard terminology of anatomical notation and orientation in fossil vertebrate dentitions. Journal of Vertebrate Paleontology 23: $1-12$.

Sterli J. 2008. A new, nearly complete stem turtle from the Jurassic of South America with implications for turtle evolution. Biology Letters 4: 286-289.

Sues H-D, Baird D. 1993. A skull of a sphenodontian lepido- saur from the New Haven Arkose (Upper Triassic:Norian) of Connecticut. Journal of Vertebrate Paleontology 13: 370-372.

Sues H-D, Olsen PE. 1990. Triassic vertebrates of Gondwanan aspect from the Richmond Basin of Virginia. Science 249: 1020-1023.

Sues H-D, Reisz RR. 1995. First record of the early Mesozoic sphenodontian Clevosaurus (Lepidosauria:Rhynchocephalia) from the Southern Hemisphere. Journal of Palaeontology 69: 123-126.

Sues H-D, Shubin NH, Olsen PE. 1994. A new sphenodontian (Lepidosauria: Rhynchocephalia) from the McCoy Brook Formation (Lower Jurassic) of Nova Scotia, Canada. Journal of Vertebrate Paleontology 14: 327-340.

Tasch P, Volkheimer W. 1970. Jurassic conchostracans from Patagonia. University of Kansas, Paleontological Contributions 50: 1-23.

Throckmorton GS, Hopson JA, Parks P. 1981. A redescription of Toxolophosaurus cloudi Olson, a Lower Cretaceous herbivorous sphenodontian reptile. Journal of Paleontology 55: 586-597.

Vogt L, Bartolomaeus T, Giribet G. 2010. The linguistic problem of morphology: structure versus homology and the standardization of morphological data. Cladistics 26: 301325 .

Whiteside DI. 1986. The head skeleton of the Rhaetian sphenodontid Diphydontosaurus avonis gen. et sp. nov., and the modernising of a living fossil. Philosophical Transactions of the Royal Society of London, B 312: 379-430.

Wiens JJ. 2003. Missing data, incomplete taxa and phylogenetic accuracy. Systematic Biology 52: 528-538.

Wiens JJ. 2005. Missing data and the design of phylogenetic analyses. Journal of Biomedical Informatics 39: 34-42.

Wu X-C. 1991. The comparative anatomy and systematics of Mesozoic sphenodontidans. Unpublished PhD Thesis, McGill University.

Wu X-C. 1994. Late Triassic-Early Jurassic sphenodontians (Clevosaurus) from China and the Phylogeny of the Sphenodontida. In: Fraser NC, Sues H-D, eds. In the shadow of the dinosaurs: Early Mesozoic tetrapods. Cambridge: Cambridge University Press, 38-69.

\section{APPENDIX \\ CHARACTER LIST}

Description of 73 characters used in the phylogenetic analyses. Characters were mainly taken from the literature (source indicated in parentheses after each character; see below), although some of them were modified (denoted with an asterisk). In addition, seven new characters regarding dentary and tooth morphology were added. Multistate characters were treated as unordered. Abbreviations: AN03, Apesteguía \& Novas (2003); B85, Benton (1985); E88, Evans (1988); FB89, Fraser \& Benton (1989); G88, Gauthier et al. (1988); R96, Reynoso (1996); R97, Reynoso (1997); RC98, Reynoso \& Clark (1998); S94, Sues et al. (1994); W94, Wu (1994). 
1. Antorbital region, length relative to skull length: one third or more (0); between one quarter and one third (1); one quarter or less (2). (S94, W94, R96, AN03)

2. Orbit, length relative to skull length: one third or greater (0); less than one third (1). (RC98, AN03)

3. Supratemporal fenestra, length relative to orbit length: less than $75 \%(0) ; 75 \%$ or greater (1). (S94, AN03)

4. Supratemporal fenestra, length relative to skull length: one quarter or less (0); more than one quarter (1). (W94, R96, AN03)

5. Lower temporal fenestra, length relative to skull length: one quarter or less (0); more than one quarter (1). (W94, R96, AN03)

6. Maxilla, premaxillary process: elongate (0); reduced (1). (S94, W94, R96, AN03)

7. Maxilla, participation in margin of external naris: entering into margin (0); excluded from margin by posterodorsal process of premaxilla (1). (S94, R97, AN03)

8. Maxilla, shape of posterior end: tapering posteriorly or very narrow (0); dorsoventrally broad (1). (W94, R96, AN03)

9. Lacrimal: present (0); absent (1). (S94, W94, R96, AN03)

10. Jugal, shape of dorsal process: broad and short (0); narrow and elongate (1). (W94, R96, AN03)

11. Prefrontal and postfrontal, profuse sculpture on bone surface: absent (0); present (1). (AN03)

12. Prefrontal-jugal contact: absent (0); present (1). (S94, R97, AN03)

13. Postorbital, marked dorsal ridge and deep ventrolateral concavity: absent (0); present (1). (AN03)

14. Frontals, relation: separated (0); fused (1). (S94, W94, R96, AN03)

15. Parietals, relation: separated (0); fused (1). (S94, W94, R96, AN03)

16. Parietal, width between supratemporal passages relative to interorbital width: broader (0); narrower (1). (S94, W94, R96, AN03)

17. Parietal crest: absent (0); present (1). (S94, W94, R96, AN03)

18. Parietal, shape of posterior edge: greatly incurved inward (0); slightly incurved inward (1); convex (2). (W94, R96, AN03)

19. Parietal foramen, position relative to anterior border of supratemporal fenestra: posterior (0); at the same level or anterior (1). (S94, W94, R96, AN03)

20. Lower temporal bar, position: aligned with the maxillary tooth row (0); bowed away beyond the limit of the abductor chamber (1). (S94, W94, R96, AN03)

21. Lower temporal bar, posteroventral process of jugal*: absent (0); poorly to moderately developed, less than half the length of the lower temporal fenestra (1); well developed, half the length of the lower temporal fenestra or more (2). (S94, W94, R96, AN03)

22. Palatine, shape of posterior end: tapers posteriorly (0); widens posteriorly (1). (S94, W94, R96, AN03)

23. Pterygoids, anterior contact between bones: small or absent (0); broad (1). (R97, AN03)

24. Pterygoids, posterior opening of the interpterygoid vacuity between posteromedial processes: widely open (0); moderately open, as wide as the vacuity (1); almost closed by the posteromedial processes (2). (R97, AN03)

25. Pterygoid, central region between three rami: short (0); elongate (1). (S94, W94, R96, AN03)

26. Pterygoid, participation in margin of suborbital fenestra: form part of the margin (0); excluded from margin (1). (S94, W94, R96, AN03)

27. Suborbital fenestra, enclosing: by more than two bones (0); only by ectopterygoid and palatine (1). (S94, R97, AN03)

28. Quadrate-quadratojugal foramen, relative size: small (0); large (1). (RC98, AN03)

29. Quadrate-quadratojugal foramen, location: between the quadrate and the quadratojugal (0); entirely within the quadrate (1). (RC98, AN03)

30. Quadrate-quadratojugal emargination, shape: pronounced (0); reduced (1). (E88, S94, W94, RC98, AN03)

31. Supratemporal, as a discrete bone: present (0); absent (1). (S94, R97, AN03)

32. Inferred jaw motion: orthal (0); propalinal (1). (S94, W94, R96, AN03)

33. Degree of propalinality, measured either as palatal tooth row extension or length over which palatines keep parallel to the maxillae: small palatal row, parallel line restricted to the anterior region (0); enlarged, palatines accompanying maxilla for half its own length (1); palatines accompanying maxilla for its complete length, 'eupropalinality' (2). (S94, W94, R96, AN03)

34. Mandibular symphysis, mentonian process*: reduced or absent (0); well developed and pointed (1); well developed and rounded (2). (AN03)

35. Mandibular symphysis, shape*: almost circular, height/length relation near one (0); oval, height/ length clearly greater than one (1). (B85, R96, AN03)

36. Mandibular symphysis, angle between anterior margin and longitudinal axis of the mandible in lateral view*: $<120^{\circ}$, symphysis nearly vertical, typically devoid of ventral projections (0); $\geq 120^{\circ}$, symphysis anterodorsally projected (1). (AN03)

37. Mandibular symphysis, symphyseal spur*: reduced or absent (0); well developed, anterodorsally projected (1); moderately developed (2). (AN03) 
38. Mandibular foramen, relative size: small (0); large (1). (B85, R96, AN03)

39. Glenoid cavity, shape: smooth surface, lacking an anteroposterior central ridge (0); elongate and asymmetrical surface, with a strong anteroposterior central ridge (1); symmetrical facet with a strong anteroposterior central ridge (2). (AN03)

40. Coronoid process, height relative to that of the jaw at the level of the anterior end of the coronoid process: low, weak, less than half the jaw (0); moderately high, around half jaw height (1); very high, nearly as high as the jaw (2). (S94, W94, R96, AN03)

41. Retroarticular process, shape: pronounced (0); reduced, caudally projected (1); reduced, dorsally curved (2). (S94, W94, R96, AN03)

42. Dentary, posterior process, relative length: short, not reaching glenoid level (0); elongate, reaching glenoid level (1); elongate, reaching the end of glenoid level (2). (S94, R97, AN03)

43. Marginal dental implantation, type: pleurodont (0); degree of posterior acrodonty (1); fully acrodont (2). (S94, W94, R96, AN03)

44. Tooth replacement, type: alternate (0); addition at back of jaw (1). (B85, R96, AN03)

45. Dentary regionalization with small juvenile teeth (hatchling) in the anterior region of maxilla and dentary: absent, only pleurodont teeth (0); present, with hatchling pleurodont teeth (1); present, with hatchling, successional and additional acrodont teeth (2); absent both in juveniles and adults, only additional acrodont teeth (3). (B85, R96, AN03)

46. Dentary, posterior successionals, number in mature individuals*: zero (0); one (1); two or more (2). (G88, R96, AN03)

47. Marginal teeth, lateral wear facets on dentary and/or medial wear facets on maxilla: absent or smooth (0); present, conspicuous (1). (S94, W94, R96, AN03)

48. Marginal teeth, shape of cross-section of posterior teeth: nearly circular (0); squared (1); rectangular, wider than long (2). (FB89, R96, AN03)

49. Premaxillary teeth, number in mature individuals: more than seven (0); seven to four (1); three or fewer (2). (S94, W94, R96, AN03)

50. Premaxillary teeth, general organization in adults: present as discrete teeth (0); merged into a chisel-like structure (1). (S94, W94, R96, AN03)

51. Maxillary teeth, posteromedial flanges on posterior teeth*: absent or inconspicuous (0); present as small flanges on at least one tooth (1); present as extensive flanges on most teeth (2). (S94, W94, R96, AN03)

52. Maxillary teeth, anterolateral flange on posterior teeth: absent (0); present (1). (AN03)
53. Palatine teeth, number of tooth rows: two or more (0); a single row plus one isolated tooth (1); a single lateral row (2). (S94, W94, R96, AN03)

54. Palatine teeth, flanges: completely absent (0); present at least on a few teeth (1). (FB89, R96, AN03)

55. Palatine teeth, hypertrophied tooth on anterior region of the palatine bone (stabbing palatine): absent (0); present (1). (AN03)

56. Pterygoid teeth, number of tooth rows: three or more (0); two (1); one or none (2). (S94, W94, R96, AN03)

57. Mandibular teeth, anterolateral flanges: absent (0); present, at least in one tooth (1). (S94, W94, R96, AN03)

58. Mandibular teeth, anteromedial flanges: absent (0); present (1). (AN03)

59. Mandibular teeth, additionals, dental ridges in adults: absent (0); present (1). (AN03)

60. Second sacral vertebra, posterior process: present, small (0); present, prominent (1); absent (2). (G88, R96, AN03)

61. Ischium, process on posterior border*: absent (0); present as small tubercle (1); present as prominent process (2). (E88, FB89, R96, AN03)

62. Humerus, length relative to length of presacral column: $\leq 0.2(0) ;>0.2(1)$. (FB89, R96, AN03)

63. Tibia, length relative to length of presacral column: $\leq 0.25(0)$; > 0.25 (1). (FB89, R96, AN03)

64. Femur, length relative to length of presacral column: $<0.3$ (0); $\geq 0.3$ (1). (FB89, R96, AN03)

65. Radius, length relative to length of presacral column: $<0.15$ (0); $\geq 0.15$ (1). (FB89, R96, AN03)

66. Skull, length (as an estimation of the body size): small, $<3 \mathrm{~cm}(0)$; medium size, between $3-10 \mathrm{~cm}$ (1); large, $>10 \mathrm{~cm}$ (2). (AN03)

67. Dentary, proportions (length/height ratio, L/H): gracile, long and low, $\mathrm{L} / \mathrm{H}<0.18(0)$; average, $\mathrm{L} / \mathrm{H}$ between $0.18-0.28$, robust, short and high, $\mathrm{L} / \mathrm{H}>0.28$ (2).

68. Dentary, successional teeth, maximum concurrent number during ontogeny: six or more (0); three to five (1); two or fewer (2).

69. Dentary, anterior successional teeth (not 'caniniform'), number in the adult: two or more clearly discrete teeth (0); one or two poorly distinct (1); none or indistinct (2).

70. Dentary, successional teeth, striation: present (0); absent (1).

71. Dentary, posterior successional teeth, lingual groove: absent (0); present (1).

72. Dentary, hatchling teeth, striation: absent (0); present (1).

73. Dentary, successional 'caniniform' teeth, shape of basal cross section: nearly circular (0); clearly oval, labiolingually compressed teeth (1). 


\section{DATA MATRIX}

Data matrix of 73 characters scored for 26 taxa used in the phylogenetic analysis. Symbols: ?, missing data or not applicable; $\mathrm{A}=0 / 1 ; \mathrm{B}=0 / 2 ; \mathrm{C}=1 / 2 ; \mathrm{D}=1 / 3$

\begin{tabular}{|c|c|c|c|c|c|c|c|c|}
\hline & 5 & $\begin{array}{l}1 \\
0\end{array}$ & $\begin{array}{l}1 \\
5\end{array}$ & $\begin{array}{l}2 \\
0\end{array}$ & $\begin{array}{l}2 \\
5\end{array}$ & $\begin{array}{l}3 \\
0\end{array}$ & $\begin{array}{l}3 \\
5\end{array}$ & $\begin{array}{l}4 \\
0\end{array}$ \\
\hline Ankylosphenodon & ???1? & ????1 & ????? & ?? ??? & ? ? ? ? & ? ? ? ? & ?1?31 & $1 ? 1 ? 1$ \\
\hline Brachyrhinodon & 21111 & 10111 & $00 ? 00$ & 00001 & 20120 & ????? & ?0?31 & $101 ? 1$ \\
\hline Clevosaurus hudsoni & 21111 & 11111 & 01000 & 10001 & 20210 & 11000 & 00131 & 00111 \\
\hline Cynosphenodon & ????? & ????? & ????? & ????? & ????? & ????? & ?1?11 & 12 ?? 1 \\
\hline Diphydontosaurus & 10000 & 00010 & 00010 & 00001 & 20100 & 00000 & 10100 & 00100 \\
\hline Eilenodon & ????? & ????? & 1???? & ????? & ????? & ????? & ?1?21 & $1 ? 120$ \\
\hline Gephyrosaurus & 00000 & 00000 & 00011 & 00001 & 20000 & 00000 & 10100 & $? 0000$ \\
\hline Godavarisaurus & ????? & ?1??? & ????? & ????? & ????? & ????? & ???31 & OB??? \\
\hline Homoeosaurus & $0 \mathrm{~A} 000$ & 00110 & $00 ? 00$ & $00 A 11$ & ?1200 & 10 ??? & 1 ??11 & $101 ? 1$ \\
\hline Kaikaifilusaurus & 01100 & 11111 & 11100 & 11111 & 01220 & 10000 & 11221 & 11120 \\
\hline Kallimodon & 01110 & ?011? & $00 ? 00$ & 11111 & 11200 & 10 ??? & 10111 & 021?1 \\
\hline Kawasphenodon & ????? & ????? & ????? & ????? & ????? & ????? & ?1??? & ????? \\
\hline Opisthias & ?1??? & 11111 & ?1100 & $11 ? 11$ & ?1220 & ????? & ?1221 & $111 ? 0$ \\
\hline Palaeopleurosaurus & 01110 & 00010 & 00101 & 11200 & 00211 & 00110 & 10011 & $1 ? 1 ? 1$ \\
\hline Pamizinsaurus & ????? & ?1??? & 0 ???? & ????? & ???21 & 1 ???0 & $001 D 1$ & $1 ? 1 ? 1$ \\
\hline Planocephalosaurus & 00000 & 00010 & 00011 & 00001 & 20200 & 00010 & 10131 & 00001 \\
\hline Pristidactylus & 11111 & 00001 & 10011 & $0001 ?$ & 00010 & $000 ? 0$ & $00 ? 00$ & $? 0000$ \\
\hline Rebbanasaurus & ????? & ??01? & ?0??? & ????? & ????? & ????? & ?0?21 & 02??? \\
\hline Sapheosaurus & $11 ? 10$ & $0 ? 1 ? 0$ & ???00 & 11111 & 01100 & 1???? & ???01 & 021?1 \\
\hline Sphenocondor & ????? & ????? & ????? & ????? & ????? & ????? & ????? & $1 \mathrm{C} 1 ? 1$ \\
\hline Sphenodon & 11111 & 00111 & 00100 & 11111 & 11221 & 10101 & 11231 & 12111 \\
\hline Sphenovipera & ????? & ????? & ????? & ????? & ????? & ????? & ?1?11 & 0 ? 1 ?? \\
\hline Theretairus & ????? & ????? & ????? & ????? & ????? & ????? & ?1?11 & 0 ???? \\
\hline Toxolophosaurus & ????? & ????? & ????? & ????? & ????? & ????? & ?1?21 & $111 ? 0$ \\
\hline Youngina & 00000 & 00000 & 00000 & 00000 & 20000 & 00000 & $? 0000$ & ? $0 ? 00$ \\
\hline \multirow[t]{3}{*}{ Zapatadon } & $10 ? 01$ & ??01? & ?1??1 & ?1?1? & 10221 & $0 ? 101$ & $01 ? 31$ & 12 ?? 1 \\
\hline & 4 & 5 & 5 & 6 & 6 & 7 & 7 & \\
\hline & 5 & 0 & 5 & 0 & 5 & 0 & 3 & \\
\hline Ankylosphenodon & 1121? & 012?? & ????? & ?0??1 & $2 ? 000$ & ?121? & ??? & \\
\hline Brachyrhinodon & 01212 & 01121 & 101?? & 1???? & $? 0000$ & 01??? & ??? & \\
\hline Clevosaurus hudsoni & 01212 & 01121 & 20110 & 11011 & 10000 & $1112 ?$ & ? 0 ? & \\
\hline Cynosphenodon & ??212 & 11121 & ?0??? & ?100? & ????? & ?1121 & 001 & \\
\hline Diphydontosaurus & 01111 & 20010 & 00000 & $000 ? 1$ & 10000 & 00000 & $01 ?$ & \\
\hline Eilenodon & 22213 & $0122 ?$ & 21210 & ?111? & ????? & ?222? & ?0? & \\
\hline Gephyrosaurus & 01000 & 20000 & $0 ? 000$ & $000 ? 0$ & ????? & 00001 & 0 ?? & \\
\hline Godavarisaurus & ??212 & $200 \mathrm{CO}$ & $1 ? 21 ?$ & ?100? & ????? & $0 \mathrm{~A} 100$ & 101 & \\
\hline Homoeosaurus & 11212 & $01 \mathrm{~A} 21$ & $200 ? ?$ & 21??1 & 21111 & 01??? & ??? & \\
\hline Kaikaifilusaurus & 22213 & 01221 & 21210 & 31111 & ????? & $1222 ?$ & ? 0 ? & \\
\hline Kallimodon & 01212 & 01121 & $202 ? ?$ & 21011 & 20000 & $1122 ?$ & ??? & \\
\hline Kawasphenodon & ??212 & ?10?? & ????? & ?110? & ????? & ?2??? & ??? & \\
\hline Opisthias & 11213 & $0102 ?$ & $2 ? 210$ & 21111 & ????? & ?122? & ??? & \\
\hline Palaeopleurosaurus & 01212 & 01121 & $1 ? 200$ & 21??1 & 10000 & $0022 ?$ & ??? & \\
\hline Pamizinsaurus & $1 ? 212$ & 0 ?A2? & $1 ? 2$ ?? & ?1?1? & ????? & 012 ?? & ? $1 ?$ & \\
\hline Planocephalosaurus & 01212 & ?0A2 0 & $1 ? 000$ & 11011 & 10000 & $01 C 00$ & ?1? & \\
\hline Pristidactylus & 00000 & 20000 & 00 ??? & $200 ? ?$ & ????? & ? 0001 & $0 ? ?$ & \\
\hline Rebbanasaurus & ??212 & 20020 & $1 ? 01$ ? & ?101? & ????? & 0A110 & 001 & \\
\hline Sapheosaurus & 0 ?2?? & $0 ? ? 21$ & ?0??? & ????1 & 20 ??? & 1122 ? & ??? & \\
\hline Sphenocondor & ?1212 & $200 ? ?$ & ????? & ???0? & ????? & OOC? 0 & 101 & \\
\hline Sphenodon & 11212 & $11 \mathrm{~A} 21$ & 10211 & 21002 & 10000 & $0 C 221$ & 000 & \\
\hline Sphenovipera & ?1212 & 211?? & ????? & ?1??? & ????? & $01 C 21$ & $1 ? ?$ & \\
\hline Theretairus & ??212 & $210 ? ?$ & ????? & ?1??? & ????? & ?12?1 & 0 ?? & \\
\hline Toxolophosaurus & ??213 & 012?? & ????? & ?11?? & ????? & ?222? & ? 0? & \\
\hline Youngina & 00000 & 20000 & $0 ? 000$ & $000 ? 0$ & 00000 & $? 0001$ & 0 ?? & \\
\hline Zapatadon & ??212 & 0 ?A?? & $1 ? 2$ ?? & 2???? & ????? & ?12?? & ??? & \\
\hline
\end{tabular}

